\title{
The Relationship Between Sunshine Duration And Air Temperature In Poland In The Face Of Contemporary Climate Change
}

\author{
Dorota Matuszko \\ Jagiellonian University \\ Krzysztof Bartoszek ( $\sim$ k.bartoszek@umcs.pl ) \\ Maria Curie-Sklodowska University https://orcid.org/0000-0002-8676-003X \\ Jakub Soroka \\ Institute of Meteorology and Water Management - National Research Institute
}

\section{Research Article}

Keywords: global warming, climate change, sunshine duration, air temperature, trends, Poland

Posted Date: June 15th, 2021

DOI: https://doi.org/10.21203/rs.3.rs-616851/v1

License: () (i) This work is licensed under a Creative Commons Attribution 4.0 International License. Read Full License 


\section{Abstract}

The aim of the work is to characterize the trends of sunshine duration (SDU) and air temperature, which may help understand the mechanism of contemporary climate change and explain its causes. The daily totals of SDU and daily data on air temperature from the years 1971-2019, from 25 synoptic stations in Poland are the basic source data. There was a growing trend in both SDU and air temperature. The series of records of the two variables showed that the points of change in the level of stabilization of the value of $S D U$ and air temperature are close to each other, and confirm known in the literature "global dimming" and "global brightening" periods. The linear regression model confirmed that sunshine duration explains well the variability of, and increase in day-time air temperature in Poland in the April-September period. In turn, changes in sunshine duration during winter have no impact on air temperature trends.

\section{Introduction}

The global rise in air temperature is one of the most important problems in the modern world. The warming of the climate system is indisputable (IPCC, 2013). In each of the last three decades, the temperature at the Earth's surface was higher than in the preceding decade and, at the same time, higher than in any of the preceding decades since 1850. According to the Copernicus Report (2020), 2019 was the second warmest year in the history of measurements in the world and the warmest in Europe. Other years of the last decade, such as 2012 (Dong et al., 2013; Wilcox et al., 2018), 2015 (Russo et al., 2015; Dong et al., 2016; Hoy et al., 2016; Ouzeau et al., 2016; Luterbacher et al., 2016; Sippel et al., 2016; Soubeyroux et al., 2016; Vicedo-Cabrera et al., 2016; Ionita et al., 2017; Muthers et al., 2017; Krzyżewska and Dyer, 2018; Tosic and Putnikovic, 2018) and 2018 (Sinclair et al., 2019; Twardosz, 2019) were anomalously warm in Europe.

The increase in the concentration of greenhouse gases in the atmosphere (IPCC 2013; Sippel et al., 2016) due to human activity, is the most often mentioned cause of "global warming". However, the relationship between the occurrence of heat waves, e.g. in 2015 and 2018, and atmospheric circulation (Dong et al., 2016; Duchez et al., 2016; lonita et al., 2017; Krzyżewska and Dyer, 2018; Sinclair et al., 2019; Twardosz, 2019), and an increase in sunshine duration (Kossowska-Cezak and Twardosz, 2019; Marsz and Styszyńska, 2019) have also been pointed out. Yet another view is presented by Sutton and Dong (2012), Dong et al. (2017) as well as Marsz and Styszyńska (2019), who claim that the increase in sunshine duration and warming in Europe is largely determined by changes in the thermal state of the World Ocean Waters (von Schuckmann et al., 2020).

According to the Copernicus Report (2020), total sunshine duration across Europe has shown a clear upward trend over the past 40 years. In 2019, the largest number of hours of sunshine duration was recorded as early as 1983. In almost all of Europe, the sunshine durations throughout the year were higher than the long-term average, while cloudiness was below the average during the first six months. Anomalously high totals of annual sunshine duration were the highest in the area from northern France to Central Europe and most of Eastern Europe. Also, the results of the research conducted in Poland on the basis of ground and satellite data in the years 1983-2018 indicate a significant increase in the total of sunshine duration in Poland in the spring and summer (Matuszko et al., 2020).

The purpose of this paper is to characterize the trends in sunshine duration (SDU) and air temperature and to determine the relationship between them based on almost 50 years of data (1971-2019) in Poland. An analysis of the relationship between the long-term course of these two climate elements using data from 25 stations located in Central Europe may help understand the mechanism of contemporary climate change and explain its causes. According to Brázdil et al. (1994), changes in sunshine duration during the period of global warming should be of particular interest. As we know, changes in the solar energy supply to the ground are a direct cause of changes in air temperature. The current climatological literature often ignores the relationship between sunshine duration and air temperature. Our study is unique in covering the whole country of Poland, and using data from close to 50 years up to 2019, which coincide with a period of a simultaneous increase in sunshine duration and temperature. The use of data from 25 stations located in various regions of the country will make it possible to indicate whether the trends in sunshine duration and air temperature are the same for the whole country, whether they occur throughout the whole year, or only in selected months, where and why the increase in sunshine duration and temperature is most visible, and whether the changes occurring in Poland are representative of a larger area of Europe.

\section{Instrumentation And Data}


The daily totals of sunshine duration and daily data on air temperature from the years 1971-2019, from 25 synoptic stations (Table 1) in Poland are the basic source data. The stations belong to the state meteorological service and operate under the Polish Institute of Meteorology and Water Management - National Research Institute (IMGW PIB). Only information from stations that met the criterion of continuity of the data series, without breaks, or with slight gaps that could be supplemented on the basis of data from neighbouring stations was used. In addition, efforts were made to ensure that the distribution of stations was as even as possible throughout the country. In the case of Kraków and Warsaw, the data on sunshine duration come from stations located in the city centre (Kraków, Jagiellonian University Observatory, Warsaw, Bielany district), while the data on temperatures come from airport stations (Kraków Balice, Warsaw Okęcie). It was necessary to use information from these additional stations because 'city' stations did not provide temperature measurements from 8 points in time. 
Table 1

Coordinates of the stations included in the study

\begin{tabular}{|c|c|c|c|c|}
\hline No. & Meteorological station & $\begin{array}{l}\text { Altitude } \\
\text { (m asl) }\end{array}$ & Latitude $\varphi$ & Longitude $\lambda$ \\
\hline 1 & Białystok & 148 & $53^{\circ} 06^{\prime}$ & $23^{\circ} 10^{\prime}$ \\
\hline 2 & Chojnice & 165 & $53^{\circ} 43^{\prime}$ & $17^{\circ} 32^{\prime}$ \\
\hline 3 & Gorzów Wlkp. & 71 & $52^{\circ} 44^{\prime}$ & $15^{\circ} 17^{\prime}$ \\
\hline 4 & Jelenia Góra & 342 & $50^{\circ} 54^{\prime}$ & $15^{\circ} 47^{\prime}$ \\
\hline 5 & Kalisz & 137 & $51^{\circ} 47^{\prime}$ & $18^{\circ} 05^{\prime}$ \\
\hline 6 & Kasprowy Wierch & 1991 & $49^{\circ} 14^{\prime}$ & $19^{\circ} 59^{\prime}$ \\
\hline 7 & Katowice & 278 & $50^{\circ} 14^{\prime}$ & $19^{\circ} 02^{\prime}$ \\
\hline 8 & Kłodzko & 356 & $50^{\circ} 26^{\prime}$ & $16^{\circ} 37^{\prime}$ \\
\hline 9 & Kołobrzeg & 3 & $54^{\circ} 11^{\prime}$ & $15^{\circ} 35^{\prime}$ \\
\hline 10 & Koszalin & 33 & $54^{\circ} 12^{\prime}$ & $16^{\circ} 09^{\prime}$ \\
\hline \multirow[t]{2}{*}{11} & Kraków UJ Obs. & 206 & $50^{\circ} 04^{\prime}$ & $19^{\circ} 58^{\prime}$ \\
\hline & Kraków Balice & 237 & $50^{\circ} 05^{\prime}$ & $19^{\circ} 48^{\prime}$ \\
\hline 12 & Lesko & 420 & $49^{\circ} 28^{\prime}$ & $22^{\circ} 21^{\prime}$ \\
\hline 13 & Łódź-Lublinek & 180 & $51^{\circ} 43^{\prime}$ & $19^{\circ} 24^{\prime}$ \\
\hline 14 & Mikołajki & 127 & $53^{\circ} 47^{\prime}$ & $21^{\circ} 35^{\prime}$ \\
\hline 15 & Opole & 163 & $50^{\circ} 38^{\prime}$ & $17^{\circ} 58^{\prime}$ \\
\hline 16 & Poznań & 88 & $52^{\circ} 25^{\prime}$ & $16^{\circ} 50^{\prime}$ \\
\hline 17 & Suwałki & 184 & $54^{\circ} 08^{\prime}$ & $22^{\circ} 57^{\prime}$ \\
\hline 18 & Szczecin Dąbie & 1 & $53^{\circ} 24^{\prime}$ & $14^{\circ} 37^{\prime}$ \\
\hline 19 & Snieżka & 1603 & $50^{\circ} 44^{\prime}$ & $15^{\circ} 44^{\prime}$ \\
\hline 20 & Terespol & 133 & $52^{\circ} 05^{\prime}$ & $23^{\circ} 37^{\prime}$ \\
\hline 21 & Toruń & 69 & $53^{\circ} 03^{\prime}$ & $18^{\circ} 36^{\prime}$ \\
\hline \multirow[t]{2}{*}{22} & Warszawa Bielany & 100 & $52^{\circ} 17^{\prime}$ & $20^{\circ} 58^{\prime}$ \\
\hline & Warszawa Okęcie & 106 & $52^{\circ} 10^{\prime}$ & $20^{\circ} 58^{\prime}$ \\
\hline 23 & Włodawa & 177 & $51^{\circ} 33^{\prime}$ & $23^{\circ} 32^{\prime}$ \\
\hline 24 & Zakopane & 855 & $49^{\circ} 18^{\prime}$ & $19^{\circ} 58^{\prime}$ \\
\hline 25 & Zielona Góra & 192 & $51^{\circ} 56^{\prime}$ & $15^{\circ} 31^{\prime}$ \\
\hline
\end{tabular}

\section{Note}

*, Kraków UJ Obs. - sunshine duration; Kraków Balice - air temperature

**, Warszawa Bielany - sunshine duration; Warszawa Okęcie - air temperature

Most of the meteorological stations represent typical conditions for suburban areas, and two of them (the summits of Kasprowy Wierch and Śnieżka) are high-mountain stations with a climate characteristic of a free atmosphere. In the period 1971-2019, half of the 25 stations had their location changed. The modification of location always resulted in the improved representativeness of 
measurements. The largest changes of location concerned the station in Koszalin in the 1970s (20 km) and Kołobrzeg in 2018 $(13 \mathrm{~km})$. A significant part of the measurement sites was subject to the extending urban development in their surroundings and the "absorption" of the area by the agglomeration. Particularly valuable data come from the sites whose surroundings did not changed significantly throughout the series: Jelenia Góra, Kasprowy Wierch, Mikołajki, Szczecin, Śnieżka, Terespol, and Zakopane. All the stations from which data were used operate in accordance with the WMO (2010) and IMGW PIB (2015).

\subsection{Sunshine duration}

At most stations of the Polish Institute of Meteorology and Water Management - National Research Institute (IMGW PIB) until the end of 2013, sunshine duration was measured using a traditional Campbell-Stokes heliograph, and since 2014 the instrument has been changed to automatic at 19 of them (CSD1 and CSD3 from Kipp \& Zonen). At the stations at Kasprowy Wierch, Kraków Obs. UJ, Poznań, Śnieżka, Warszawa-Bielany, and Gorzów data still come from a traditional Campbell-Stokes heliograph. At each station, sunshine duration measuring instruments are installed in a place that guarantees access to sunlight throughout the year, usually on a tower equipped with stairs, or on the roof of a building.

In order to ascertain the highest quality of data, a thorough process of selection of synoptic station was applied. The heliographic materials obtained from IMGW-PIB were analysed in detail in terms of the instrument used, length of the measurement sequence, breaks in data recording, current measurements, and data correctness. Fifty stations with sufficiently long data series (since 1971) were separated from all the 168 stations measuring sunshine duration in Poland. After supplementing the missing data and as a result of further verification of materials, 25 synoptic stations at which temperature series were also homogeneous qualified for selection. Small data gaps were supplemented using the method of similarity to the nearest station. Errors in the value of the daily total of actual sunshine duration consisting in exceeding the length of the day were eliminated using the formula of Forsythe et al. (1995) for the length of the day. For the series of data from stations where the measuring instrument was changed in 2014, a statistical analysis was performed, which showed that the conversion of data from automatic instruments to a traditional heliograph did not results in statistically significant differences in most cases; in other words, adding 'automatic' data to the data from the heliograph did not significantly affect the inclination of the linear time trend. Moreover, analysis of simultaneous comparative measurements of CSD and the Campbell-Stokes heliograph at four stations (Kasprowy Wierch, Kraków, Gorzów, Warszawa-Bielany) did not show the necessity of applying correction coefficients. Heliographic data from the above-mentioned stations were also used in previously published works (Bartoszek et al., 2020; Bartoszek et al., 2021; Matuszko et al., 2020).

\subsection{Air temperature}

Up to the end of 2004, mercury thermometers were used for air temperature measurements at the synoptic stations included in the study. Since 2005, Pt100 resistance temperature detectors, which use resistance changes resulting from temperature changes, have been used. Throughout the whole period, the instruments were placed in a Stevenson screen at a height of $2 \mathrm{~m}$ above the ground. Comparative studies have shown good compliance of the indications of both types of instruments, and the change in the measurement method did not affect the breaking of the homogeneity of the measurement series (Lorenc, 2006).

The air temperature measurement series in the years 1971-2019 contained only a few gaps. The longest, a 20-month period of lack of data concerned the station in Mikołajki (1992-1993). Other gaps included single days or single observations. Missing data were supplemented by the regression method using data from neighbouring stations (Stahl et al., 2006).

\section{Methodology}

The verification and homogenization of series of records of sunshine duration and air temperature was carried out first. Next, monthly totals of actual sunshine duration were calculated based on daily totals. In the case of air temperature, the 'daylight average' was calculated according to the author's method (Bartoszek et al., 2020), which consisted of calculating average temperatures at the following times of the day depending on the season:

- summer (May-June-July) - 06:00, 09:00, 12:00, 15:00, 18:00 UTC

- winter (November-December-January) - 09:00, 12:00, 15:00 UTC

- transitional (February-March-April and August-September-October) - 06:00, 09:00, 12:00, 15:00 UTC 
This method of calculating the averages eliminated temperatures before sunrise and after sunset (without sunshine duration). Since it gave the best correlation results with sunshine duration among all other methods of calculating the average value (Fig. 1), it was considered the most suitable for the purpose of this study.

Based on the 'daily' temperature, monthly averages for individual stations were calculated, followed by area averages. The variability of area-average sunshine duration and air temperature in individual months in the period 1971-2019 was presented in the form of a 5-class quantile classification.

Data interpolation was performed using the ordinary kriging method, using the Golden Software's Surfer 16 program. The maps show the values and statistical significance of the linear trend slope coefficients of sunshine duration ( $\mathrm{hr} / 10$ years) and air temperature $\left({ }^{\circ} \mathrm{C} / 10\right.$ years $)$ at the analysed meteorological stations. The statistical significance of the trends of the analysed variables was assessed using the Mann-Kendall test, and the magnitude of changes over time (directional coefficient) was calculated using the Sen method (Sen, 1968; Kendall, 1975).

The last stage of the study comprised analyses of the relationships between the area-average monthly day-time air temperature and sunshine duration, which were aimed at interpreting the trends in air temperature in Poland. To explain the temporal variability of the area-average day-time air temperature (1971-2019), $T_{m}$, in the month $m, m=1.2, \ldots, 12$, the following linear regression model was adopted:

$$
T_{m}=b_{0, m}+b_{1, m} S D U_{m}+\epsilon_{m}, m=1,2, \ldots, 12
$$

where:

$T_{m}$ - area-average day-time air temperature in the month $m$ in ${ }^{\circ} \mathrm{C}$

$b_{0, m}, b_{1, m}-$ regression coefficients

$S D U_{m}$ - area-average monthly sunshine duration in the month $m$ in hours

$\in_{m}$ - uncorrelated model residuals, $\mathrm{N}\left(0, \sigma_{m}\right)$ distributed

The parameters of the model (1) were calculated by the least squares method applied to linear regression of $T$ on $S D U$. The fitting quality was determined using the coefficient of determination $\left(R^{2}\right)$ and root mean square error (RMSE).

\section{Results}

\subsection{Spatial distribution of the sums of annual sunshine duration and the average annual air temperature in Poland}

Annual totals of sunshine duration are between around 1,460 hours in the south and south-west of the country (mountain areas) to more than 1,750 hours in the north - the area of the eastern Baltic coast (Fig. 2a). One area of large sunshine duration (over 1,700 hours) stretches in a wedge-like fashion to the south of the central part of the South Baltic Coast to the Silesian Lowland. Another area with the highest sunshine duration value (over 1,750) is located in the central-eastern part of Poland, including a fragment of the North Podlasie and the South Podlasie Lowlands, as well as the Western Polesie. In the largest area of the country, the central part of Poland, sunshine duration is between 1,650 to 1,700 hours per year, and gradually decreases from the centre towards the south-west, south, and north-east. A wedge-like area of reduced sunshine duration stretches from the mountainous areas to the centre of the country along the Vistula valley. The areas on the north-eastern edges of Poland have lower sunshine duration values compared to neighbouring areas.

The average annual air temperature in Poland is between $11^{\circ} \mathrm{C}$ in Lower Silesia to $0^{\circ} \mathrm{C}$ in the mountainous regions in the south and south-west of the country. Generally, the temperature decreases from the south-west towards the north-east. The spatial variability of the average annual temperature in Poland (except for mountainous areas) does not exceed $3^{\circ} \mathrm{C}$. The area with the highest temperature values (above $10^{\circ} \mathrm{C}$ ) stretches from the western end of the Pomeranian Lake District, through the Wielkopolska 
Lowland, to Lower Silesia. Apart from mountainous and upland regions, the lowest average annual temperature (below $8^{\circ} \mathrm{C}$ ) occurs in north-eastern Poland, near Suwałki (Fig. 2b).

\subsection{The annual variability of sunshine duration and air temperature}

In the course of a year, day-time air temperature changes occur with about a one-month delay compared to changes in sunshine duration. The maximum annual sunshine duration falls on the transition between June and July (Fig. 3a), while the maximum temperature falls on the transition between July and August (Fig. 3b). The curves plotted on the basis of daily area-average values from the years 1971-2019 are irregular owing to the interference caused by variations in the supply of solar radiation and changes in air temperature. Irregularities can occur from day to day, which means that the effects of inter-day changes in sunshine duration and temperature have not been levelled even for the long-term curve. Some disturbances in the annual course are particularly large and occur over a few days in a row. In the case of sunshine duration, for example, these are days in April or June when there is a temporary decline in the value with a general trend of growth, followed by a rapid increase (Fig. 3a). It is similar with the course of temperature. A few days' periods of cooling with rising temperature in the spring or periods of warming with falling temperature in the autumn occur regularly, though not necessarily every year.

\subsection{The multi-annual course of area-averages}

The multi-annual course of sunshine duration and air temperature on the basis of data from 25 stations in Poland shows an increasing trend. In the first research period (1971-1980) in the last decade of what is known in the literature as the "global dimming" (inter alia Norris and Wild 2007; Sanchez-Lorenzo et al. 2009), the values of both elements dropped to a minimum in 1980 (Fig. 4), and then gradually increased in line with the "global brightening" trend. There was a significant correspondence between the courses of sunshine duration and of temperature in shorter periods, and the lowest and highest values of both elements were recorded in the same years (Fig. 4). Until 1990, the totals of annual sunshine duration ranged from 1,278 hours (1980) to 1,795 hours (1982), and by the year 2000 they oscillated on average between 1,550 and 1,650 hours. In the following years of the 21st century, the annual values were often higher than 1,800 hours, and in 2018 they even exceeded 2,000 hours, reaching their maximum in the analysed multi-year period (Fig. 5). Like sunshine duration, the mean area annual air temperature also dropped until 1980 $\left(6.7^{\circ} \mathrm{C}\right)$. This was followed by the period of higher temperatures exceeding $9^{\circ} \mathrm{C}$ and dropping to $7{ }^{\circ} \mathrm{C}$ in $1985,1987,1996$. In 2000 , the mean annual area air temperature for the first time exceeded $10^{\circ} \mathrm{C}$ and after a drop in $2010\left(8^{\circ} \mathrm{C}\right)$ it did not fall below $9^{\circ} \mathrm{C}$, and in $2014,2015,2018,2019$ it again exceeded $10^{\circ} \mathrm{C}$, reaching a maximum of $10.9^{\circ} \mathrm{C}$ in the last year.

The values of the totals of sunshine duration in individual years are clearly reflected (Fig. 5) in the number of hot days $\left(T_{\max }>25^{\circ} \mathrm{C}\right)$, very hot days $\left(T_{\max }>30^{\circ} \mathrm{C}\right)$, and hot nights $\left(T_{\min }>20^{\circ} \mathrm{C}\right)$. This dependence applies to both area averages and data series from individual stations. In the first decade of research, the decrease in sunshine duration and temperature was accompanied by a lower incidence of the thermal characteristics mentioned, and in the following years there were increases and decreases in the number of characteristic days depending on the value of the total of sunshine duration. A clear increase in the incidence of hot days was recorded in most years in the 21 st century, and very hot days after 2011. Hot nights started to appear sporadically after 1992, and the intensification of their incidence was marked in the last decade of the analysed multi-year period (Fig. 5). The correlation coefficients between sunshine duration and the discussed thermal characteristics were $0.82,0.63$ and 0.50 , respectively.

The increase in the totals of sunshine duration and air temperature in individual months of the studied multi-year period is very clearly visible in the quantile classification (Fig. 6). From the last decade of the 20th century to the end of the studied period, the predominance of months with the highest quantile values at the same time for sunshine duration and temperature, is clearly noticeable (Fig. 6). The co-occurrence of the annual averages of both elements in the highest quintile had not happened until 2008. In recent years, however, this situation has been repeated more and more often. In the second decade of the 21 st century, it has already occurred six times (in 2011, 2014, 2015, 2016, 2018, and 2019). Moreover, the simultaneous highest values of sunshine duration and temperature frequently occurred together in single months in the last two decades. They happened most frequently in: 2019 (February, April, June, August, October, December), 2018 (April, May, August, September, October), 2015 (March, August, September, October), and 2006 (June, July, September, December). It is worth noting that in each month since 1971, the highest quintile values often occurred simultaneously for both sunshine duration and temperature, most of them (9) in June and September, and least (1) in January. In the last three years of the examined period, August was the sunniest and warmest (Fig. 6).

Page $7 / 28$ 
The simultaneous annual values of sunshine duration and temperature were in the lowest quintile for the last time in 1995 (Fig. 6). The least sunny and coolest summer months (July and August) occurred in the years 1977-1981 and in June 1980. For the air temperature alone, despite the general trend of its increase, there are months in which the values are in the lowest quintile. This applies to all seasons except the summer, i.e. the months from January to May and from October to December. The spring months at the beginning of the surveyed multi-year period were particularly cold. From 1972, for ten consecutive years, air temperature values in April were classified in the lowest quintile. Moreover, the months of May in this decade were cold, except for 1975, 1979, 1981 (Fig. 6). On the other hand, not all winter months have been exceptionally warm in the last decade. Only in December (with the exception of 2012) high and very high temperatures occurred, while in January values below normal were most prevalent.

Sunshine durations also trend upwards, but there is a large variation in their totals in individual months. In a given year, a month belonging to the highest quintile may precede a month with the lowest quintile (e.g., November and December 2018). For example, in 2019, in April, May, and June, the months with the highest quintiles of both sunshine duration and temperature were separated by a month from the lowest quintile (Fig. 6).

\subsection{Spatial variability of trends in sunshine duration and air temperature}

Considering annual values, the trends in sunshine duration in Poland are more spatially varied than air temperature. The largest increase in sunshine duration (over $130 \mathrm{hr} / 10$ years) occurred at the stations in Opole, Jelenia Góra, and Katowice (south-western Poland, except mountainous areas) and decreased to the east, with a minimum value at the north-eastern end of the country (Suwałki - $33 \mathrm{hr} / 10$ years) (Fig. 7a). Air temperature increased most $\left(0.5^{\circ} \mathrm{C} / 10\right.$ years) in Małopolska and Silesia Uplands (Kraków, Opole). Increase in temperature was stronger in the central and eastern parts of the country (Suwałki, Terespol) than in the west (Kołobrzeg, Śnieżka, Kłodzko), and in the south-east of Poland (Fig. 7b, Table 2). 
Table 2

Directional coefficients of trends in sunshine duration ( $\mathrm{hr} / 10$ years) and air temperature $\left({ }^{\circ} \mathrm{C} / 10\right.$ years) at the analysed meteorological stations in Poland (1971-2019)

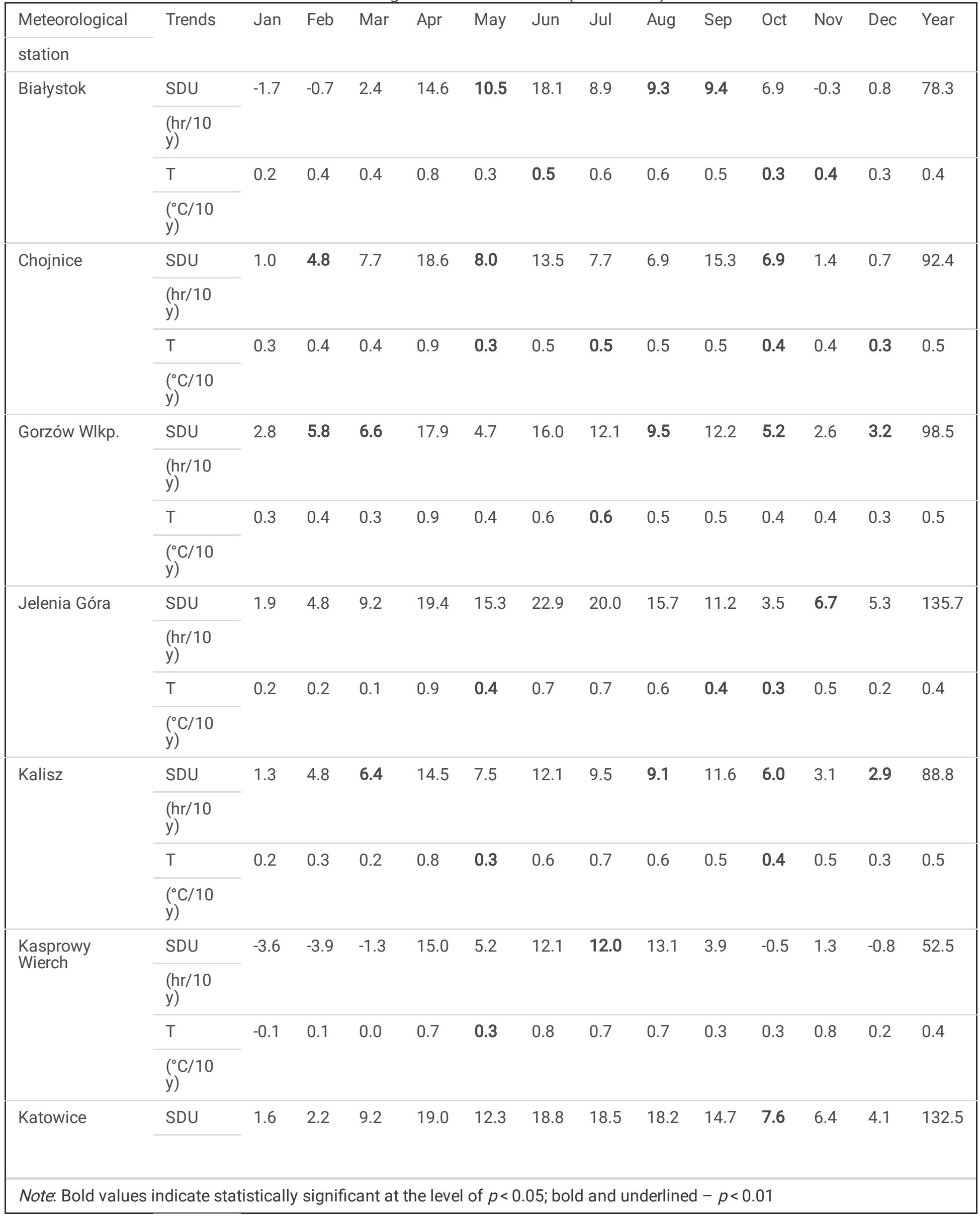




\begin{tabular}{|c|c|c|c|c|c|c|c|c|c|c|c|c|c|c|}
\hline & $\begin{array}{l}(\mathrm{hr} / 10 \\
\mathrm{y})\end{array}$ & & & & & & & & & & & & & \\
\hline & $\mathrm{T}$ & 0.2 & 0.3 & 0.2 & 0.9 & 0.4 & 0.8 & 0.7 & 0.7 & 0.5 & 0.4 & 0.7 & 0.3 & 0.5 \\
\hline & $\begin{array}{l}\left({ }^{\circ} \mathrm{C} / 10\right. \\
\mathrm{y})\end{array}$ & & & & & & & & & & & & & \\
\hline Kłodzko & SDU & -1.1 & 3.2 & 6.1 & 15.0 & 7.6 & 12.2 & 10.0 & 8.2 & 9.1 & 0.4 & 2.2 & 0.3 & 73.2 \\
\hline & $\begin{array}{l}(\mathrm{hr} / 10 \\
\mathrm{y})\end{array}$ & & & & & & & & & & & & & \\
\hline & $\mathrm{T}$ & 0.1 & 0.2 & 0.2 & 0.8 & 0.3 & 0.6 & 0.7 & 0.6 & 0.4 & 0.3 & 0.6 & 0.2 & 0.4 \\
\hline & $\begin{array}{l}\left({ }^{\circ} \mathrm{C} / 10\right. \\
\mathrm{y})\end{array}$ & & & & & & & & & & & & & \\
\hline Kołobrzeg & SDU & 0.6 & 2.8 & 6.4 & 11.9 & 5.9 & 14.0 & 8.5 & 2.1 & 10.9 & 1.6 & 1.1 & -2.1 & 63.8 \\
\hline & $\begin{array}{l}(\mathrm{hr} / 10 \\
\mathrm{y})\end{array}$ & & & & & & & & & & & & & \\
\hline & $\mathrm{T}$ & 0.3 & 0.3 & 0.3 & 0.7 & 0.4 & 0.5 & 0.4 & 0.4 & 0.4 & 0.3 & 0.4 & 0.3 & 0.4 \\
\hline & $\begin{array}{l}\left({ }^{\circ} \mathrm{C} / 10\right. \\
\mathrm{y})\end{array}$ & & & & & & & & & & & & & \\
\hline Koszalin & SDU & 1.8 & 3.7 & 8.5 & 15.6 & 6.4 & 16.0 & 12.2 & 3.5 & 15.0 & 6.1 & 3.9 & 0.1 & 92.8 \\
\hline & $\begin{array}{l}(\mathrm{hr} / 10 \\
\mathrm{y})\end{array}$ & & & & & & & & & & & & & \\
\hline & $\mathrm{T}$ & 0.3 & 0.4 & 0.3 & 0.8 & 0.3 & 0.5 & 0.5 & 0.5 & 0.5 & 0.4 & 0.4 & 0.3 & 0.4 \\
\hline & $\begin{array}{l}\left({ }^{\circ} \mathrm{C} / 10\right. \\
\mathrm{y})\end{array}$ & & & & & & & & & & & & & \\
\hline Kraków & SDU & 2.3 & 2.6 & 8.8 & 15.9 & 9.5 & 12.5 & 13.8 & 13.1 & 11.4 & 5.6 & 2.8 & 4.9 & 103.0 \\
\hline & $\begin{array}{l}(\mathrm{hr} / 10 \\
\mathrm{y})\end{array}$ & & & & & & & & & & & & & \\
\hline & $\mathrm{T}$ & 0.3 & 0.4 & 0.3 & 0.9 & 0.4 & 0.8 & 0.8 & 0.7 & 0.5 & 0.4 & 0.6 & 0.3 & 0.5 \\
\hline & $\begin{array}{l}\left({ }^{\circ} \mathrm{C} / 10\right. \\
\mathrm{y})\end{array}$ & & & & & & & & & & & & & \\
\hline Lesko & SDU & -2.6 & -1.0 & 0.5 & 16.9 & 8.8 & 13.6 & 13.8 & 14.8 & 9.6 & 5.2 & 3.9 & 1.5 & 85.1 \\
\hline & $\begin{array}{l}(\mathrm{hr} / 10 \\
\mathrm{y})\end{array}$ & & & & & & & & & & & & & \\
\hline & $\mathrm{T}$ & 0.0 & 0.2 & 0.1 & 0.8 & 0.3 & 0.7 & 0.6 & 0.7 & 0.4 & 0.4 & 0.8 & 0.2 & 0.4 \\
\hline & $\begin{array}{l}\left({ }^{\circ} \mathrm{C} / 10\right. \\
\mathrm{y})\end{array}$ & & & & & & & & & & & & & \\
\hline Łódź-Lublinek & SDU & -1.1 & 1.9 & 4.1 & 15.3 & 7.2 & 15.6 & 8.0 & 8.8 & 10.9 & 6.1 & 2.2 & 2.3 & 81.3 \\
\hline & $\begin{array}{l}(\mathrm{hr} / 10 \\
\mathrm{y})\end{array}$ & & & & & & & & & & & & & \\
\hline & $\mathrm{T}$ & 0.3 & 0.3 & 0.2 & 0.9 & 0.4 & 0.7 & 0.7 & 0.6 & 0.5 & 0.4 & 0.6 & 0.3 & 0.5 \\
\hline & $\begin{array}{l}\left({ }^{\circ} \mathrm{C} / 10\right. \\
\mathrm{y})\end{array}$ & & & & & & & & & & & & & \\
\hline Mikołajki & SDU & -1.0 & 0.7 & 4.5 & 16.7 & 7.6 & 11.0 & 7.2 & 6.3 & 10.1 & 4.5 & -1.5 & -0.5 & 65.6 \\
\hline
\end{tabular}




\begin{tabular}{|c|c|c|c|c|c|c|c|c|c|c|c|c|c|c|}
\hline & $\begin{array}{l}(\mathrm{hr} / 10 \\
\mathrm{y})\end{array}$ & & & & & & & & & & & & & \\
\hline & $\mathrm{T}$ & 0.1 & 0.3 & 0.4 & 0.8 & 0.5 & 0.5 & 0.9 & 0.9 & 0.9 & 0.3 & 0.3 & 0.2 & 0.5 \\
\hline & $\begin{array}{l}\left({ }^{\circ} \mathrm{C} / 10\right. \\
\mathrm{y})\end{array}$ & & & & & & & & & & & & & \\
\hline Opole & SDU & 4.3 & 6.0 & 10.1 & 19.4 & 11.3 & 18.5 & 16.3 & 15.6 & 13.6 & 8.1 & 6.7 & 6.7 & 136.7 \\
\hline & $\begin{array}{l}(\mathrm{hr} / 10 \\
\mathrm{y})\end{array}$ & & & & & & & & & & & & & \\
\hline & $\mathrm{T}$ & 0.2 & 0.2 & 0.2 & 0.9 & 0.4 & 0.8 & 0.8 & 0.7 & 0.5 & 0.4 & 0.7 & 0.2 & 0.5 \\
\hline & $\begin{array}{l}\left({ }^{\circ} \mathrm{C} / 10\right. \\
\mathrm{y})\end{array}$ & & & & & & & & & & & & & \\
\hline Poznań & SDU & 1.4 & 2.8 & 4.1 & 18.8 & 6.5 & 15.8 & 13.8 & 14.0 & 12.0 & 4.0 & 3.5 & 0.1 & 96.7 \\
\hline & $\begin{array}{l}(\mathrm{hr} / 10 \\
\mathrm{y})\end{array}$ & & & & & & & & & & & & & \\
\hline & $\mathrm{T}$ & 0.3 & 0.3 & 0.3 & 0.9 & 0.4 & 0.6 & 0.6 & 0.6 & 0.6 & 0.4 & 0.5 & 0.3 & 0.5 \\
\hline & $\begin{array}{l}\left({ }^{\circ} \mathrm{C} / 10\right. \\
\mathrm{y})\end{array}$ & & & & & & & & & & & & & \\
\hline Suwałki & SDU & -1.8 & -3.0 & 1.9 & 12.5 & 3.4 & 7.7 & 2.9 & 2.1 & 7.8 & 2.9 & -1.7 & -1.3 & 33.4 \\
\hline & $\begin{array}{l}(\mathrm{hr} / 10 \\
\mathrm{y})\end{array}$ & & & & & & & & & & & & & \\
\hline & $\mathrm{T}$ & 0.3 & 0.4 & 0.5 & 0.9 & 0.4 & 0.5 & 0.6 & 0.6 & 0.6 & 0.3 & 0.5 & 0.4 & 0.5 \\
\hline & $\begin{array}{l}\left({ }^{\circ} \mathrm{C} / 10\right. \\
\mathrm{y})\end{array}$ & & & & & & & & & & & & & \\
\hline Szczecin Dąbie & SDU & 1.9 & 4.8 & 5.4 & 16.8 & 4.6 & 13.3 & 9.3 & 5.2 & 13.0 & 5.5 & 2.6 & 1.2 & 83.5 \\
\hline & $\begin{array}{l}(\mathrm{hr} / 10 \\
\mathrm{y})\end{array}$ & & & & & & & & & & & & & \\
\hline & $\mathrm{T}$ & 0.3 & 0.4 & 0.3 & 0.8 & 0.3 & 0.5 & 0.4 & 0.4 & 0.4 & 0.4 & 0.4 & 0.3 & 0.4 \\
\hline & $\begin{array}{l}\left({ }^{\circ} \mathrm{C} / 10\right. \\
\mathrm{y})\end{array}$ & & & & & & & & & & & & & \\
\hline Śnieżka & SDU & -2.5 & -1.5 & 2.3 & 13.3 & 5.1 & 15.2 & 13.8 & 8.9 & 3.5 & -2.4 & 1.9 & -0.8 & 56.8 \\
\hline & $\begin{array}{l}(\mathrm{hr} / 10 \\
\mathrm{y})\end{array}$ & & & & & & & & & & & & & \\
\hline & $\mathrm{T}$ & 0.1 & 0.1 & 0.2 & 0.8 & 0.3 & 0.7 & 0.6 & 0.5 & 0.3 & 0.3 & 0.7 & 0.2 & 0.4 \\
\hline & $\begin{array}{l}\left({ }^{\circ} \mathrm{C} / 10\right. \\
\mathrm{y})\end{array}$ & & & & & & & & & & & & & \\
\hline Terespol & SDU & -4.4 & -3.0 & 4.9 & 16.0 & 12.0 & 15.7 & 9.2 & 10.2 & 12.0 & 6.1 & -0.2 & -0.2 & 78.2 \\
\hline & $\begin{array}{l}(\mathrm{hr} / 10 \\
\mathrm{y})\end{array}$ & & & & & & & & & & & & & \\
\hline & $\mathrm{T}$ & 0.3 & 0.4 & 0.4 & 0.8 & 0.4 & 0.6 & 0.7 & 0.7 & 0.6 & 0.4 & 0.5 & 0.3 & 0.5 \\
\hline & $\begin{array}{l}\left({ }^{\circ} \mathrm{C} / 10\right. \\
\mathrm{y})\end{array}$ & & & & & & & & & & & & & \\
\hline Toruń & SDU & 0.2 & 3.4 & 5.2 & 16.0 & 2.9 & 10.5 & 3.7 & 5.0 & 9.3 & 5.7 & 0.7 & 1.0 & 63.5 \\
\hline
\end{tabular}




\begin{tabular}{|c|c|c|c|c|c|c|c|c|c|c|c|c|c|c|}
\hline & $\begin{array}{l}(\mathrm{hr} / 10 \\
\mathrm{y})\end{array}$ & & & & & & & & & & & & & \\
\hline & $\mathrm{T}$ & 0.2 & 0.3 & 0.3 & 0.9 & 0.4 & 0.6 & 0.6 & 0.6 & 0.5 & 0.4 & 0.5 & 0.3 & 0.5 \\
\hline & $\begin{array}{l}\left({ }^{\circ} \mathrm{C} / 10\right. \\
\mathrm{y})\end{array}$ & & & & & & & & & & & & & \\
\hline Warszawa & SDU & -0.5 & 0.5 & 3.8 & 13.9 & 8.3 & 16.1 & 10.2 & 10.2 & 10.8 & 5.4 & -0.1 & 0.8 & 79.4 \\
\hline & $\begin{array}{l}(\mathrm{hr} / 10 \\
\mathrm{y})\end{array}$ & & & & & & & & & & & & & \\
\hline & $\mathrm{T}$ & 0.3 & 0.4 & 0.3 & 0.8 & 0.4 & 0.6 & 0.7 & 0.6 & 0.5 & 0.4 & 0.5 & 0.3 & 0.5 \\
\hline & $\begin{array}{l}\left({ }^{\circ} \mathrm{C} / 10\right. \\
\mathrm{y})\end{array}$ & & & & & & & & & & & & & \\
\hline Włodawa & SDU & -2.6 & -1.7 & 2.0 & 11.5 & 8.1 & 13.4 & 5.7 & 5.8 & 7.7 & 7.4 & 0.8 & 0.9 & 59.0 \\
\hline & $\begin{array}{l}\text { (hr/10 } \\
\mathrm{y})\end{array}$ & & & & & & & & & & & & & \\
\hline & $\mathrm{T}$ & 0.3 & 0.4 & 0.4 & 0.8 & 0.3 & 0.6 & 0.7 & 0.7 & 0.5 & 0.4 & 0.6 & 0.3 & 0.5 \\
\hline & $\begin{array}{l}\left({ }^{\circ} \mathrm{C} / 10\right. \\
\mathrm{y})\end{array}$ & & & & & & & & & & & & & \\
\hline Zakopane & SDU & -0.4 & -1.8 & 2.1 & 13.8 & 4.5 & 7.3 & 8.1 & 7.4 & 2.0 & 0.7 & 3.2 & 1.7 & 48.5 \\
\hline & $\begin{array}{l}(\mathrm{hr} / 10 \\
\mathrm{y})\end{array}$ & & & & & & & & & & & & & \\
\hline & $\mathrm{T}$ & 0.1 & 0.2 & 0.2 & 0.9 & 0.3 & 0.7 & 0.7 & 0.7 & 0.4 & 0.3 & 0.7 & 0.2 & 0.5 \\
\hline & $\begin{array}{l}\left({ }^{\circ} \mathrm{C} / 10\right. \\
\mathrm{y})\end{array}$ & & & & & & & & & & & & & \\
\hline Zielona Góra & SDU & 1.0 & 5.0 & 6.7 & 19.0 & 6.7 & 16.9 & 12.8 & 10.6 & 11.2 & 4.6 & 3.9 & 2.4 & 100.8 \\
\hline & $\begin{array}{l}(\mathrm{hr} / 10 \\
\mathrm{y})\end{array}$ & & & & & & & & & & & & & \\
\hline & $\mathrm{T}$ & 0.2 & 0.3 & 0.2 & 0.9 & 0.4 & 0.6 & 0.5 & 0.5 & 0.4 & 0.4 & 0.4 & 0.3 & 0.4 \\
\hline & $\begin{array}{l}\left({ }^{\circ} \mathrm{C} / 10\right. \\
\mathrm{y})\end{array}$ & & & & & & & & & & & & & \\
\hline
\end{tabular}

In January and February, trends in sunshine duration decrease longitudinally and are positive (4.3 hr/10 years, Opole) in the western half of Poland, and negative in the eastern half $(-4.4 \mathrm{hr} / 10$ years, Terespol). Air temperature increases during these months, but the trends are not statistically significant and change latitudinally, from the highest values in the north to the lowest in the south (Fig. 8, Table 2). In March, the largest trends in sunshine duration occur in the central Baltic coast ( $8.5 \mathrm{hr} / 10$ years, Koszalin) and Silesian Upland (10.1 hr/10 years, Opole), while the smallest are in the Bieszczady Mountains and the belt in north-eastern and south-eastern Poland (Fig. 8). Temperature trends in March increase from the south-west and south to the north-east, but are small and not statistically significant. The largest increases in the length of sunshine duration and the value of temperature in a 10-year period in the year occur in April. For both elements they are the largest in the west of Poland $\left(19.4 \mathrm{hr} / 10\right.$ years, $0.9^{\circ} \mathrm{C} / 10$ years, Jelenia Góra and Opole) and decrease towards the east (Fig. 8). It is worth noting that a large increase in temperature also occurred in the mountains in April (Zakopane, Śnieżka, Kasprowy Wierch). In May, trend values do not vary much and are statistically significant only at very few stations (Table 2). In the summer months, the highest increases in sunshine duration are observed in the south-west of Poland (Jelenia Góra, Katowice, Opole) and decrease towards the north-east in June and July, and towards the north in August (Fig. 8). In these months, the temperature also increased the most in the south-west $\left(0.8^{\circ} \mathrm{C} / 10\right.$ years Opole, Kraków), and the trends decreased towards the north-west. Interestingly, a large increase in temperature $\left(0.8-0.7^{\circ} \mathrm{C} / 10\right.$ years $)$ occurred in the mountains, at the stations on Kasprowy Wierch, Zakopane, and Śnieżka (Table 2). In September, trends in sunshine duration were the largest in 
Western Pomerania (Koszalin, Chojnice) and the Silesian Upland (Katowice, Opole), while the smallest occurred in the mountains and in the east of Poland (Fig. 8, Table 2). Temperature trends in September were the highest in the north-east (Mikołajki:

$0.9^{\circ} \mathrm{C} / 10$ years) and gradually decreased towards the south and south-west. In October, November, and December, slight increases in sunshine duration occurred at only very few stations in south-western Poland, while positive temperature trends were clearly marked in November (Fig. 8, Table 2). Also in November, the highest temperature increase was recorded in southern Poland $\left(0.8^{\circ} \mathrm{C} / 10\right.$ years, Kasprowy Wierch, Lesko), and the values gradually decreased towards the north. In December, positive trends in sunshine duration in south-western Poland are not reflected in temperature trends. They increase slightly in the northern half of Poland, but the trends are not statistically significant (Table 2).

\subsection{Correlation between sunshine duration and air temperature}

A correlation analysis of the area-average monthly sunshine duration and air temperature shows a strong relationship between them in the period from April to October (Fig. 9). The highest correlation coefficients occur in July and September $(r=0.87)$. Sunshine duration is less related to the maximum temperature than to the average daily temperature, because the $T_{\max }$ value relates only to one time during the day. The highest correlation coefficients between SDU and $T_{\max }$ occur in June and August $(r>0.60)$, i.e. in months other than the ones with the highest correlation coefficients between $S D U$ and the average air temperature (Fig. 9). A more pronounced relationship between sunshine duration and temperature in the warm half-year means that in this part of the year the radiation factor has a greater effect on air temperature than the circulation of the atmosphere.

The highest correlation coefficients between the average annual air temperature and sunshine duration $(r>0.80)$ were found at stations in the southern part of the country, i.e. in Kraków, Katowice, and Opole, while the least $(r<0.60)$ in Suwałki (north-eastern Poland) (Fig. 10a). In winter, at the stations located in the northern and eastern half of the country, the correlation coefficients are negative, however, they are statistically significant only in Suwałki and Białystok ( $r=-0.46$ and -0.41 , respectively) (Fig. 10b). In the other seasons, the association is positive; for example, in April, the correlation between sunshine duration and air temperature is statistically significant at all meteorological stations, and the highest correlation coefficient values occur in southern and western Poland $(0.68<r \leq 0.72)$ while the lowest in the eastern part of the country $(0.49<r \leq 0.55)$ (Fig. 10c). The correlation coefficients in July are the highest in the year, i.e., $r>0.80$ at many stations (Fig. 10). In July, similarly to April, a slightly lower correlation occurs in eastern Poland $(0.70<r \leq 0.75)$ (Fig. 10d). In October, the correlation of temperature and sunshine duration is low, especially in northern Poland $(r<0.30)$, and statistically significant only at the stations in the southern half of the country $(r>0.40)($ Fig. 10e).

A strong statistically significant relationship between the average day-time air temperature and the sunshine duration facilitated development of linear regression models reflecting the course of air temperature in individual months in the years 1971-2019. The high degree of agreement of data calculated with the models with the values from meteorological stations from April-September is confirmed by the low values of the RMSE indicator (Table 3). The totals of sunshine duration account for from $41 \%$ (in May) to $76 \%$ (in July) of the air temperature variances in the warm half of the year. The average day-time air temperature values from the AprilSeptember period, both from meteorological stations and from the model, show a strong upward trend, with the highest values occurring in the last two years of the studied multi-year period, i.e., in 2018 and 2019 (Fig. 11). 
Table 3

Estimation results of the linear regression model (1) of area-average monthly day-time air temperature in Poland in the years 19712019

\begin{tabular}{|c|c|c|c|c|c|c|}
\hline Month & Model equation & $R^{2}$ & $\begin{array}{l}\text { F- } \\
\text { value }\end{array}$ & $\begin{array}{l}\mathrm{p}- \\
\text { value }\end{array}$ & $\begin{array}{l}\text { RMSE } \\
\left({ }^{\circ} \mathrm{C}\right)\end{array}$ & $\begin{array}{l}T \\
\left({ }^{\circ} \mathrm{C}\right)\end{array}$ \\
\hline Jan & & 0.003 & 1.14 & 0.291 & 2.8 & -1.5 \\
\hline Feb & & 0.001 & 0.21 & 0.652 & 2.9 & -0.8 \\
\hline Mar & & 0.062 & 3.95 & 0.053 & 2.2 & 3.1 \\
\hline Apr & & 0.443 & 39.26 & 0.000 & 1.3 & 8.6 \\
\hline May & & 0.412 & 34.64 & 0.000 & 1.2 & 14.1 \\
\hline Jun & & 0.645 & 88.24 & 0.000 & 0.9 & 17.1 \\
\hline Jul & & 0.757 & 150.58 & 0.000 & 0.9 & 19.1 \\
\hline Aug & & 0.599 & 72.65 & 0.000 & 1.0 & 18.8 \\
\hline Sep & & 0.746 & 142.16 & 0.000 & 0.9 & 14.1 \\
\hline Oct & & 0.187 & 12.02 & 0.001 & 1.4 & 8.9 \\
\hline Nov & & 0.013 & 0.99 & 0.324 & 1.9 & 4.0 \\
\hline Dec & & 0.005 & 0.56 & 0.458 & 2.2 & 0.1 \\
\hline Year & & 0.612 & 76.59 & 0.000 & 0.6 & 8.8 \\
\hline
\end{tabular}

\section{Discussion Of The Results}

In Poland, as well as elsewhere in Europe, increasing trends in sunshine duration (among others Norris and Wild, 2007; SanchezLorenzo et al., 2007; Sanchez-Lorenzo et al., 2008; Manara et al., 2015; Sanchez-Lorenzo, 2015) and in air temperature (among others Hoy et al., 2016; Luterbacher et al., 2016; Sippel et al., 2016; Soubeyroux et al., 2016; Vicedo-Cabrera et al., 2016; Muthers et al., 2017; Krzyżewska and Dyer, 2018; Tosic and Putnikovic, 2018; Sinclair et al., 2019) have been observed in the last 40 years. The research results presented in this study on the basis of data from 1971-2019 in Poland show that the growing trends in these two elements have not been consistent throughout the entire studied period: it is not evident in all months of the year, and is spatially varied.

The temporal and spatial variability of the climate elements analysed here is determined by Poland's location in the zone of moderate latitudes. The annual course of sunshine duration and temperature depends on radiation and circulation factors. Disturbances in the annual cycle of both elements are associated with atmospheric circulation (Fig. 3). In the spring, for example, 
when the temperature generally rises, there are periods in a year when the temperature drops significantly or its growth is stopped on the climatological curves (climatograms) plotted based on daily data. In June, despite more favourable astronomical conditions (a longer day) than in May and July, both sunshine duration and air temperature are lower (Fig. 3). This is likely caused by a great amount of cloudiness associated with the reconstruction of the circulation system in Europe and the intensification of air advection from the west and north-west, which occurs at the end of June (Brooks, 1946; Lamb, 1950; Kaszewski, 1983). This results in a decrease in sunshine duration and a lower air temperature. In the autumn, i.e., at the end of September or at the beginning of October, when the temperature generally decreases, there is a temporary slowdown in sunshine duration decrease and a several-day warming-up period occurring in individual years. Atmospheric circulation and its changes, which create conditions for the occurrence of cold advection and heat advection in Poland, are the main factors generating disturbances in the annual course of sunshine duration and air temperature.

The records of sunshine duration and temperature showed that the change of the value of both elements fall on the same years or those that are close to each other (Fig. 4). The first decades may include the "global dimming" period (e.g., Liepert, 2002; Norris and Wild, 2007; Manara et al., 2015; Sanchez-Lorenzo, 2015). The second period, in which there is a rapid increase in sunshine duration ("global brightening") begins in Poland in 1989. This is also a breakthrough year in the temperature trend changes, confirmed also by the studies by Marsz and Styszyńska (2019). As results of studies conducted in various regions indicate, the reduction in aerosol optical thickness (AOT) had the greatest impact on the increase in sunshine duration (including Provençal et al., 2017; Mukkavilli et al., 2019; Bartoszek et al., 2021) and on the decrease in the incidence of low-level clouds, mainly stratiform clouds (e.g., Clement et al., 2009; Sherwood et al., 2014). Trends in the supply of solar radiation based on ground and satellite data on the Iberian Peninsula in the years 1985-2015 are similar to the trends in sunshine duration in Poland and are also explained by the changes in cloudiness and a decrease in AOT (Montero-Martin et al., 2020).

In the multi-year course, the least sunny and coolest months of the warm half of the year occurred in Poland in years 1977-1981 (Fig. 6), because those years were the cloudiest (Matuszko and Węglarczyk, 2018) and there was the largest aerosol content in Poland (Bartoszek et al., 2021). Aerosols are known to affect the supply of solar radiation both directly and indirectly through the role they play in cloud formation (Ramanathan et al., 2001). Thus, in addition to circulation reasons, the high cloudiness in the 5year period between 1977-1981 and the low sunshine duration in its summer months may have been associated with the impact of aerosols on the intensification of cloud-forming processes. According to Sanchez-Lorenzo et al. (2008), the period of low sunshine duration in the years from 1960 to 1980 was associated with high cloudiness accompanying low pressure systems, while the decrease in cloudiness was caused by the predominance of high pressure systems in the last two decades of the 20th century. Matuszko and Węglarczyk (2015) point out that the increase in air temperature is associated more with a change in the structure of cloudiness than with changes in the degree of cloudiness, and the relationship between these elements is more evident in the second half of the 20th century, when climate warming accelerated. In many regions of the world, an increase in the incidence of vertical clouds, a decrease in the incidence of stratiform clouds, and a more frequent occurrence of high-level clouds (e.g., Sun and Groisman, 2000; Wibig, 2008; Eastman and Warren, 2013; Matuszko and Węglarczyk, 2018) have been observed particularly in the last forty-year period.

The highest increase in sunshine duration and air temperature occurred in Poland in the second decade of the 21st century (Fig. 4) and applies to the months of the warm half of the year, especially April (Fig. 5), which may result from the fact that at the beginning of the surveyed multi-year period (the 1970s) the spring months in Poland were anomalously cold (Fig. 6). Similarly, in Spain, the largest increase in solar radiation occurred in the spring, which is mainly explained by the decrease in cloudiness at this time of the year (Trigo et al., 2002; Sanchez-Lorenzo et al., 2009; Tzallas et al., 2019). Using data from the years 1951-2018 from the 210 meteorological stations in Europe and Asia Minor, and on the northern coast of Africa, Kossowska-Cezak and Twardosz (2019) showed that the 1970s were the coldest period in the multi-year course, that is, they had the highest incidence of extremely cold months and seasons and the lowest incidence of unusually warm months and seasons.

In Poland, there is a large spatial variability in the directional coefficients of trends in the annual and monthly totals of sunshine duration, as well as in average annual and monthly air temperature. The highest increase in sunshine duration occurred in southwestern Poland, except for mountainous areas, and the smallest at its north-eastern end (Table 2). South-western Poland is a highly industrialized area that was most polluted during the "global dimming" period. Improving air quality and reducing the AOT value had an impact on the largest increase in sunshine duration in this area (Matuszko et al., 2020).

Page $15 / 28$ 
In Poland, there is a strong relationship between day-time air temperature and sunshine duration expressed by high positive values of correlation coefficients, but only during the warm half of the year. In winter, a positive correlation ( $r$ between 0.25 and 0.35 ) is observed in southern Poland, which may be influenced by the occurrence of foehn phenomena on the leeward side of the mountains (Elvidge and Renfrew, 2016). An inverse relationship between temperature and sunshine duration is observed in eastern Poland (Fig. 10b), which is due to the impact of high pressure systems from Eastern Europe in this part of the country, which in the winter, usually during cloudless weather, contribute to the occurrence of cold waves (Tomczyk et al., 2019). The linear regression model confirmed that sunshine duration explains well the variability of, and increase in day-time air temperature in Poland in the AprilSeptember period in the years 1971-2019 (Fig. 11). It is worth noting that the 10 years with the highest average day-time temperatures in the warm season of the year occurred after 2000, and 6 of them in the second decade of the 21 st century.

\section{Conclusions}

Climate warming, especially evident in the 21 st century, is a fact. This research, carried out in Poland, allows us to conclude that different factors influence the increase in temperature in the warm and cool halves of the year. We have shown that the increase in air temperature from April to September is largely determined by the increase in sunshine duration ( $R^{2}$ from 0.41 in May to 0.76 in July). The reason for the increase in sunshine duration is an issue requiring further research. The possible causes could be simply a decrease in the content of aerosols in the atmosphere; alternatively, a change in the amount and structure of cloudiness caused by a change in atmospheric circulation, or changes in the content of water vapour in the atmospheric column.

A separate issue is the increase in air temperature in the cool half of the year. Our research results indicate that changes in sunshine duration during this period have no impact on air temperature trends. Therefore, in winter months, non-radiation factors including primarily - atmospheric circulation in the ocean-atmosphere system, play a key role in the global warming.

The presented work is the basis for further research on the impact of increased sunshine duration and temperature on the economy of Poland e.g., on the development of solar energy or viticulture.

\section{Declarations}

\section{Funding:}

not applicable

\section{Conflicts of interest/Competing interests:}

not applicable

\section{Availability of data and material (data transparency):}

Information regarding ground-based data: The source of data is the Institute of Meteorology and Water Management - National Research Institute. Data from the Institute of Meteorology and Water Management - National Research Institute were processed.

\section{Code availability (software application or custom code):}

STATISTICA 13.0 software (TIBCO Software Inc., StatSoft Inc., Tulsa, OK, USA).

\section{Authors' contributions:}

Dorota Matuszko: Conceptualization, Methodology, Writing-Original draft preparation, Investigation, Supervision, Writing-Reviewing and Editing

Krzysztof Bartoszek: Data curation, Software, Visualization, Validation, Writing-Reviewing and Editing, Writing-Original draft preparation

Jakub Soroka: Data curation, Resources, Writing-Reviewing and Editing 


\section{References}

1. Bartoszek K, Matuszko D, Soroka J (2020) Relationships between cloudiness, aerosol optical thickness, and sunshine duration in Poland. Atmos Res 245:105097. https://doi.org/10.1016/j.atmosres.2020.105097

2. Bartoszek K, Matuszko D, Węglarczyk S (2021) Trends in sunshine duration in Poland (1971-2018). Int J Climatol 41(1):73-91. https://doi.org/10.1002/joc.6609

3. Brázdil R, Flocas A, Sahsamanoglou H (1994) Fluctuation of sunshine duration in central and South-Eastern Europe. Int J Climatol 14(9):1017-1034. https://doi.org/10.1002/joc.3370140907

4. Brooks CEP (1946) Annual recurrences of weather: 'singularities'. Weather 1(4):107-113. https://doi.org/10.1002/j.14778696.1946.tb00060.x

5. Clement AC, Burgman R, Norris JR (2009) Observational and model evidence for positive low-level cloud feedback. Science 325(5939):460-465. https://doi.org/10.1126/science.1171255

6. Copernicus Report (2020) https://climate.copernicus.eu/sites/default/files/2020-04/ESOTC2019_summary.pdf. Accessed 18 October 2020

7. Dong B, Sutton R, Shaffrey L (2017) Understanding the rapid summer warming and changes in temperature extremes since the mid-1990s over Western Europe. Clim Dyn 48(5-6):1537-1554. https://doi.org/10.1007/s00382-016-3158-8

8. Dong B, Sutton R, Shaffrey L, Wilcox L (2016) The 2015 European heat wave. Bull Am Met Soc 97(12):57-62. https://doi.org/10.1175/BAMS-D-16-0149

9. Dong B, Sutton R, Woollings T (2013) The extreme European summer 2012. Bull Am Met Soc 94(9):28-32. https://doi.org/10.1175/BAMS-D-13-00085.1

10. Duchez A, Frajka-Williams E, Josey SA, Evans DG, Grist JP, Marsh R, McCarthy GD, Sinha B, Berry DI, Hirschi JJ-M (2016) Drivers of exceptionally cold North Atlantic Ocean temperatures and their link to the 2015 European heat wave. Environ Res Lett 11(7):074004. https://doi.org/10.1088/1748-9326/11/7/074004

11. Eastman R, Warren SG (2013) A 39-Yr Survey of Cloud Changes from Land Stations Worldwide 1971-2009: Long-Term Trends, Relation to Aerosols, and Expansion of the Tropical Belt. J Clim 26:1286-1303. https://doi.org/10.1175/JCLI-D-12-00280.1

12. Elvidge AD, Renfrew IA (2016) The causes of foehn warming in the lee of mountains. Bull Am Met Soc 97:455-466. https://doi.org/10.1175/BAMS-D-14-00194.1

13. Forsythe WC, Rykiel EJ Jr, Randal S, Schoolfield RM (1995) A model comparison for daylength as a function of latitude and day of year. Ecol Model 80(1):87-95. https://doi.org/10.1016/0304-3800(94)00034-F

14. Hoy A, Hänsel S, Skalak P, Ustrnul Z, Bochníček O (2016) The extreme European summer of 2015 in a long-term perspective. Int J Climatol 37:943-962. https://doi.org/10.1002/joc.4751

15. IMGW-PIB (2015) Instrukcja dla stacji meteorologicznych (Manual for meteorological stations (in Polish)

16. Ionita M, Tallaksen L, Kingston D, Stagge J, Laaha G, Van Lanen H, Scholz P, Chelcea S, Haslinger K (2017) The European 2015 drought from a climatological perspective. Hydrol Earth Syst Sci 21:1397-1419. https://doi.org/10.5194/hess-21-1397-2017

17. IPCC (2013) In: Stocker TF, Qin D, Plattner G-K, Tignor M, Allen SK, Boschung J, Nauels A, Xia Y, Bex V, Midgley PM (eds) Climate Change 2013: The Physical Science Basis. Contribution of Working Group I to the Fifth Assessment Report of the Intergovernmental Panel on Climate Change. Cambridge: Cambridge University Press

18. Kaszewski BM (1983) Próba wydzielenia naturalnych okresów synoptycznych na podstawie częstości typów cyrkulacji nad Polską (An attempt to seperate natural synoptic periods based on the frequency of circulation types over Poland). Prz Geof 28(2):195-207 (in Polish)

19. Kendall MG (1975) Rank correlation measures. Charles Griffin, London

20. Kossowska-Cezak U, Twardosz R (2019) Wielkoobszarowe anomalie termiczne w Europie (1951-2018) (Large-area thermal anomalies in Europe (1951-2018). IGiGP UJ, Kraków (in Polish)

21. Krzyżewska A, Dyer J (2018) The August 2015 mega-heatwave in Poland in the context of past events. Weather 72(7):207-204. https://doi.org/10.1002/wea.3244

22. Lamb HH (1950) Types and spells of weather around the year in the British Isles: Annual trends, seasonal structure of the year, singularities. QJR Meteorol Soc 76:393-429. https://doi.org/10.1002/qj.49707633005

Page $17 / 28$ 
23. Liepert BG (2002) Observed reductions of surface solar radiation at sites in the United States and worldwide from 1961 to 1990. Geophys Res Lett 29(10):1421. https://doi.org/10.1029/2002GL014910

24. Lorenc H (2006) Ocena jakości danych meteorologicznych po wprowadzeniu automatycznych przyrządów rejestrujących na sieci IMGW (Assessment of meteorological data quality after the introduction of automatic measurement devices on the IMGWPIB network). Annales UMCS sec B 61:256-266 (in Polish)

25. Luterbacher J, Werner JP, Smerdon JE, Fernández-Donado L, González-Rouco FJ, Barriopedro D, Ljungqvist FC, Büntgen U, Zorita E, Wagner S, Esper J, McCarroll D, Toreti A, Frank D, Jungclaus JH, Barriendos M, Bertolin C, Bothe O, Brázdil R, Camuffo D, Dobrovolný P, Gagen M, García-Bustamante E, Ge Q, Gómez-Navarro JJ, Guiot J, Hao Z, Hegerl GC, Holmgren K, Klimenko VV, Martín-Chivelet J, Pfister C, Roberts N, Schindler A, Schurer A, Solomina O, von Gunten L, Wahl E, Wanner H, Wetter O, Xoplaki E, Yuan N, Zanchettin D, Zhang H, Zerefos C (2016) European summer temperatures since Roman times. Environ Res Lett 11(2):024001. https://doi:10.1088/1748-9326/11/2/024001

26. Manara V, Beltrano MC, Brunetti M, Maugeri M, Sanchez-Lorenzo A, Simolo C, Sorrenti S (2015) Sunshine duration variability and trends in Italy from homogenized instrumental time series (1936-2013). J Geophys Res 120(9):3622-3641. https://doi.org/10.1002/2014JD022560

27. Marsz AA, Styszyńska A (2019) Skala i przyczyny zmian temperatury najcieplejszych miesięcy roku nad obszarem Polski po roku 1988 (The scale and causes of changes in the temperature of the warmest months of the year over the area of Poland after 1988) In: Chojnacka-Ożga L., Lorenc H (Eds.) Współczesne problemy klimatu Polski. IMGW-PIB, Polskie Towarzystwo Geofizyczne 9-26 (in Polish)

28. Matuszko D, Bartoszek K, Soroka J, Węglarczyk S (2020) Sunshine duration in Poland from ground- and satellite-based data. Int J Climatol 40(9):4259-4271. https://doi.org/10.1002/joc.6460

29. Matuszko D, Węglarczyk S (2015) Relationship between sunshine duration and air temperature and contemporary global warming. Int J Climatol 35:3640-3653. https://doi.org/10.1002/joc.4238

30. Matuszko D, Węglarczyk S (2018) Long-term variability of the cloud amount and cloud genera and their relationship with circulation (Kraków, Poland). Int J Climatol 38(51):1205-1220. https://doi.org/10.1002/joc.5445

31. Montero-Martín J, Antón M, Vaquero-Martínez J, Sanchez-Lorenzo A (2020) Comparison of long-term solar radiation trends from CM SAF satellite products with ground-based data at the Iberian Peninsula for the period 1985-2015. Atmos Res 236:104839. https://doi.org/10.1016/j.atmosres.2019.104839

32. Mukkavilli SK, Prasad A, Taylor RA, Huang J, Mitchell RM, Kay M (2019) Assessment of atmospheric aerosols from two reanalysis products over Australia. Atmos Res 215:149-164. https://doi.org/10.1016/j.atmosres.2018.08.026

33. Muthers S, Laschewski G, Matzarakis A (2017) The summers 2013 and 2015 in South-West Germany: heat waves and heatrelated mortality in the context of climate change. Atmosphere 8(11):224. https://doi.org/10.3390/atmos8110224

34. Norris JR, Wild M (2007) Trends in aerosol radiative effects over Europe inferred from observed cloud cover solar "dimming" and solar "brightening". J Geophys Res 112(D8):1-13. https://doi.org/10.1029/2006JD007794

35. Ouzeau G, Soubeyroux J-M, Schneider M, Vautard R, Planton S (2016) Heat waves analysis over France in present and future climate: Application of a new method on the EURO-CORDEX ensemble. Clim Serv 4:1-12. https://doi.org/10.1016/j.cliser.2016.09.002

36. Provençal S, Kishcha P, da Silva AM, Elhacham E, Alpert P (2017) AOD distributions and trends of major aerosol species over a selection of the world's most populated cities based on the 1st version of NASA's MERRA Aerosol Reanalysis. Urban Clim 20:168-191. https://doi.org/10.1016/j.uclim.2017.04.001

37. Ramanathan V, Crutzen PJ, Kiehl JT, Rosenfeld D (2001) Aerosols, climate and the hydrological cycle. Science 294(5549):21192124. https://doi.org/10.1126/science.1064034

38. Russo S, Sillmann J, Fischer EM (2015) Top ten European heatwaves since 1950 and their occurrence in the coming decades. Environ Res Lett 10:124003. https://doi:10.1088/1748-9326/10/12/124003

39. Sanchez-Lorenzo A (2015) Reassessment and update of long-term trends in downward surface shortwave radiation over Europe (1939-2012). J Geophys Res 120(18):9555-9569. https://doi.org/10.1002/2015jd023321

40. Sanchez-Lorenzo A, Brunetti B, Calbo J, Martin-Vide J (2007) Recent spatial and temporal variability and trends of sunshine duration over the Iberian Peninsula from a homogenized data set. J Geophys Res 112(D20). 
https://doi.org/10.1029/2007JD008677

41. Sanchez-Lorenzo A, Calbó J, Martin-Vide J (2008) Spatial and temporal trends in sunshine duration over Western Europe (1938-2004). J Clim 21(22):6089-6098. https://doi.org/10.1175/2008JCLI2442.1

42. Sanchez-Lorenzo A, Calbó J, Brunetti M, Deser C (2009) Dimming/brightening over the Iberian Peninsula: Trends in sunshine duration and cloud cover and their relations with atmospheric circulation. J Geophys Res 114(D10):D00D09. https://doi.org/10.1029/2008JD011394

43. Sen PK (1968) Estimates of the regression coefficient based on Kendall's tau. J Am Stat Assoc 63(324):1379-1389. https://doi.org/10.2307/2285891

44. Sherwood SC, Bony S, Dufresne JL (2014) Spread in model climate sensitivity traced to atmospheric convective mixing. Nature 505:37-42. https://doi.org/10.1038/nature12829

45. Sinclair VA, Mikkola J, Rantanen M, Räisänen J (2019) The summer 2018 heatwave in Finland. Weather 74(11):403-409. https://doi.org/10.1002/wea.3525

46. Sippel S, Otto FEL, Flach M, van Oldenborgh GJ (2016) The Role of Anthropogenic Warming in 2015 Central European Heat Waves. Bull Am Met Soc 97:51-56. https://doi.org/10.1175/BAMS-D-16-0150.1

47. Soubeyroux M, Ouzeau G, Schneider M, Cabanes O, Kounkou R (2016) Les vagues de chaleur en France: analyse de l'été 2015 et évolutions attendues en climat futur. La Météorologie 94:45-51 (in French)

48. Stahl K, Moore RD, Floyer JA, Asplin MG, McKendry IG (2006) Comparison of approaches for spatial interpolation of daily air temperature in a large region with complex topography and highly variable station density. Agric For Meteorol 139(3-4):224236. https://doi.org/10.1016/j.agrformet.2006.07.004

49. Sun B, Groisman PY (2000) Cloudiness variations over the former Soviet Union. Int J Climatol 20(10):1097-1111. https://doi.org/10.1002/1097-0088(200008)20:10<1097::AID-JOC541>3.0.C0;2-5.

50. Sutton RT, Dong B (2012) Atlantic Ocean influence on a shift in European climate in the 1990s. Nat Geosci 5:788-792. https://doi.org/10.1038/ngeo1595

51. Tomczyk AM, Bednorz E, Półrolniczak M, Kolendowicz L (2019) Strong heat and cold waves in Poland in relation with the largescale atmospheric circulation. Theor Appl Climatol 137(3-4):1909-1923. https://doi.org/10.1007/s00704-018-2715-y

52. Tosic I, Putnikovic S (2018) Heat waves in Serbia during the summer season. EGU General Assembly Conference. Geophys Res Abstr 20:EGU2018-2105

53. Trigo R, Osborn T, Corte-Real J (2002) The North Atlantic oscillation influence on Europe: climate impacts and associated physical mechanisms. Clim Res 20(1):9-17. https://doi.org/10.3354/cr020009

54. Twardosz R (2019) Anomalously warm months in 2018 in Poland in relation to circulation patterns. Weather 74(11):374-382. https://doi.org/10.1002/wea.3588

55. Tzallas V, Hatzianastassiou N, Benas N, Meirink J, Matsoukas C, Stackhouse P, Vardavas I (2019) Evaluation of CLARA-A2 and ISCCP-H cloud cover climate data records over Europe with ECA\&D ground-based measurements. Remote Sens 11(2):212. https://doi.org/10.3390/rs11020212

56. Vicedo-Cabrera A, Ragettli M, Schindler C, Röösli M (2016) Excess mortality during the warm summer of 2015 in Switzerland. Swiss Medical Weekly 146:1-12. https://doi.org/10.4414/smw.2016.14379

57. von Schuckmann K et al (2020) Heat stored in the Earth system: where does the energy go? Earth Syst Sci Data 12:2013-2041. https://doi.org/10.5194/essd-12-2013-2020

58. Wibig J (2008) Cloudiness variations in Łódź in the second half of the 20th century. Int J Climatol 28(4):479-491. https://doi.org/10.1002/joc.1544

59. Wilcox LJ, Yiou P, Hauser M, Lott FC, van Oldenborgh GJ, Colfescu I, Dong B, Hegerl G, Shaffrey L, Sutton R (2018) Multiple perspectives on the attribution of the extreme European summer of 2012 to climate change. Clim Dyn 50:3537-3555. https://doi.org/10.1007/s00382-017-3822-7

60. WMO (2010) Guide to Meteorological Instruments and Methods of Observation, seventh edition, updated 2010, WMO - No.8 Geneva

\section{Figures}

Page 19/28 


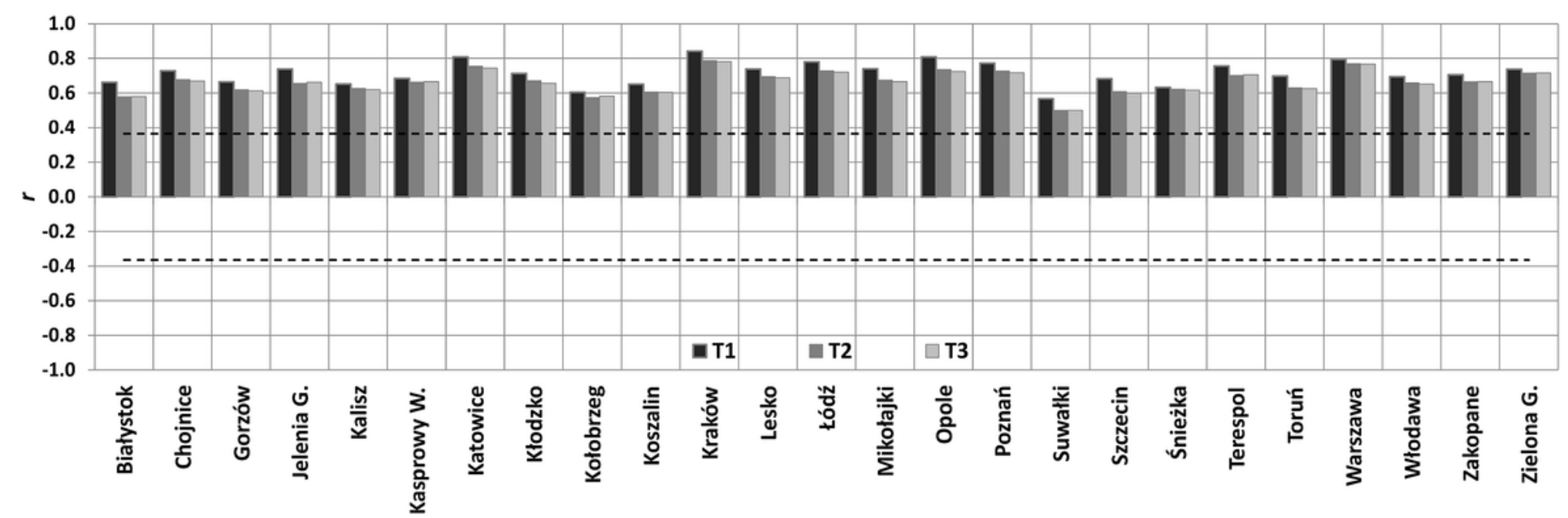

\section{Figure 1}

Correlation coefficients between the average annual totals of sunshine duration and the average annual air temperature at individual stations calculated using different methods. T1 - day-time average temperature calculated according to the author's method (winter: from 3 observations; spring and autumn from 4 observations; summer from 5 observations); T2 - daily average temperature calculated from 8 observations; T3 - daily average temperature calculated from formula: T6+T18+Tmax+Tmin /4

a)

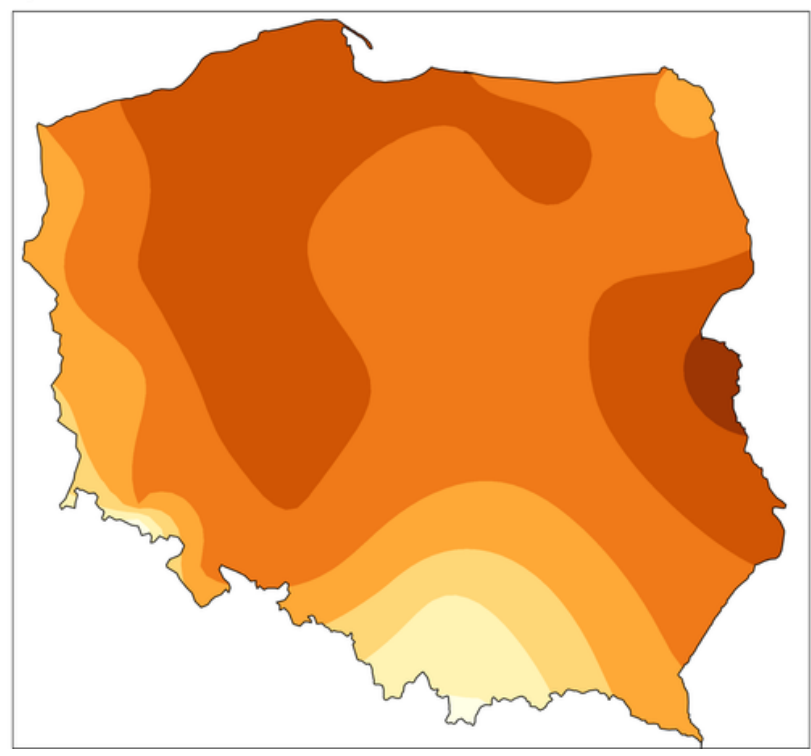

b)

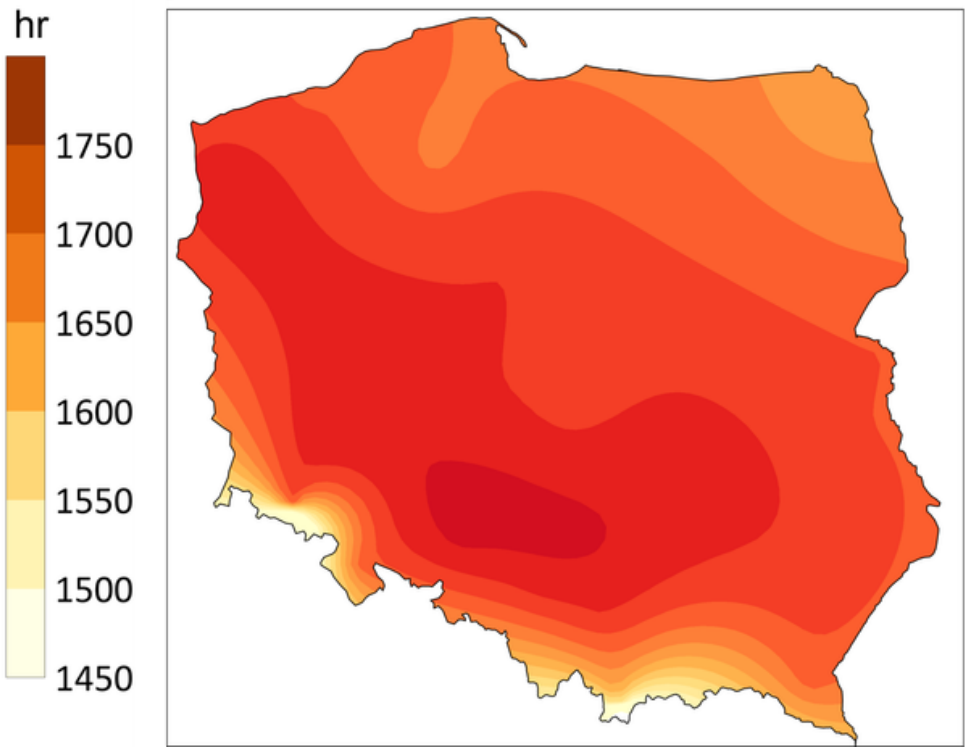

${ }^{\circ} \mathrm{C}$

11.0 10.0 9.0 8.0 7.0 6.0 5.0 4.0 3.0 2.0

\section{Figure 2}

The 1971-2019 average annual (a) sunshine duration and (b) day-time air temperature in Poland 
a)

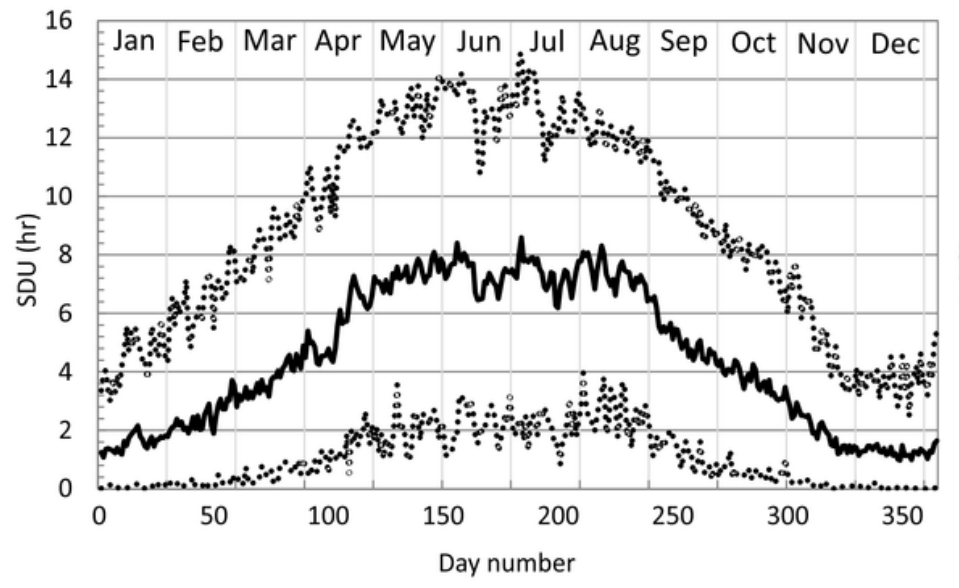

b)

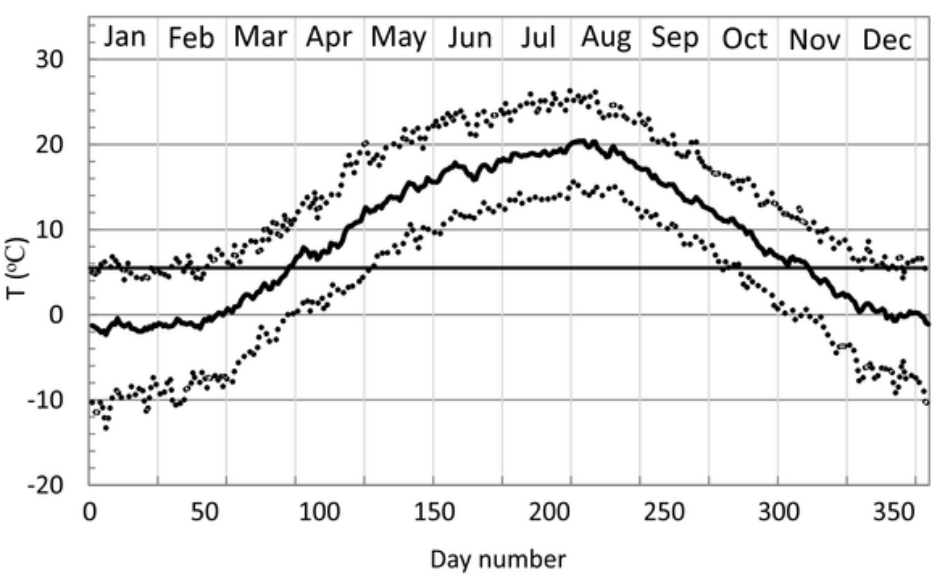

Figure 3

The annual variability of area-average daily values of (a) sunshine duration and (b) day-time air temperature in Poland. The thick black line refers to the average values from the period 1971-2019; the dashed line - 5th and 95th percentile values

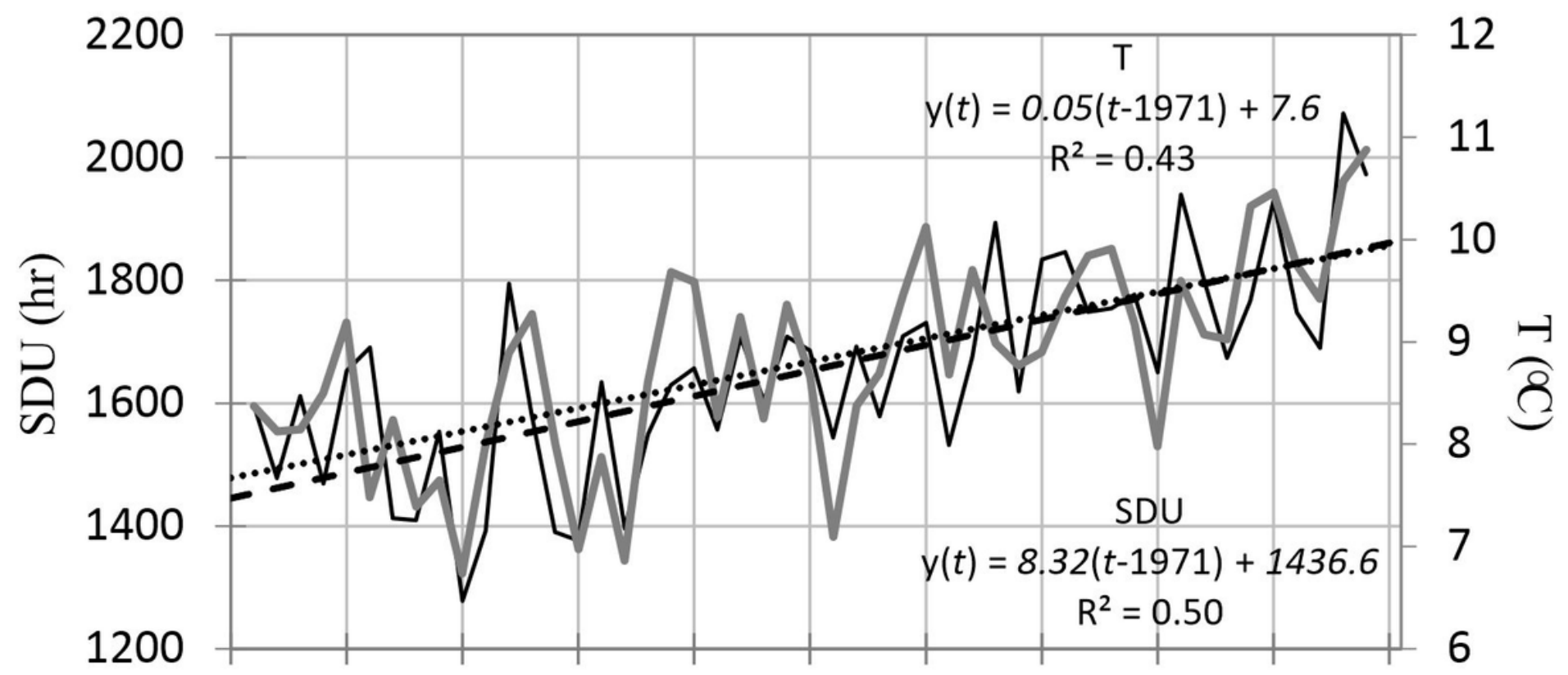

19701975198019851990199520002005201020152020

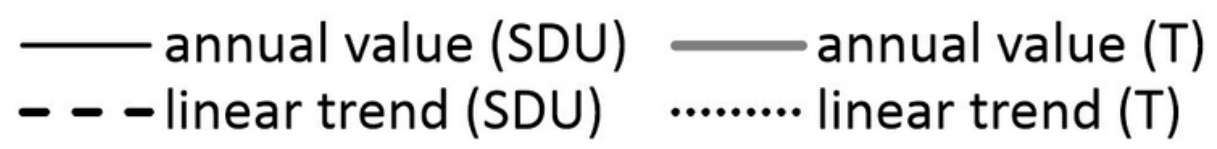

Figure 4

The multi-annual course of area-average annual sunshine duration and day-time air temperature in Poland 


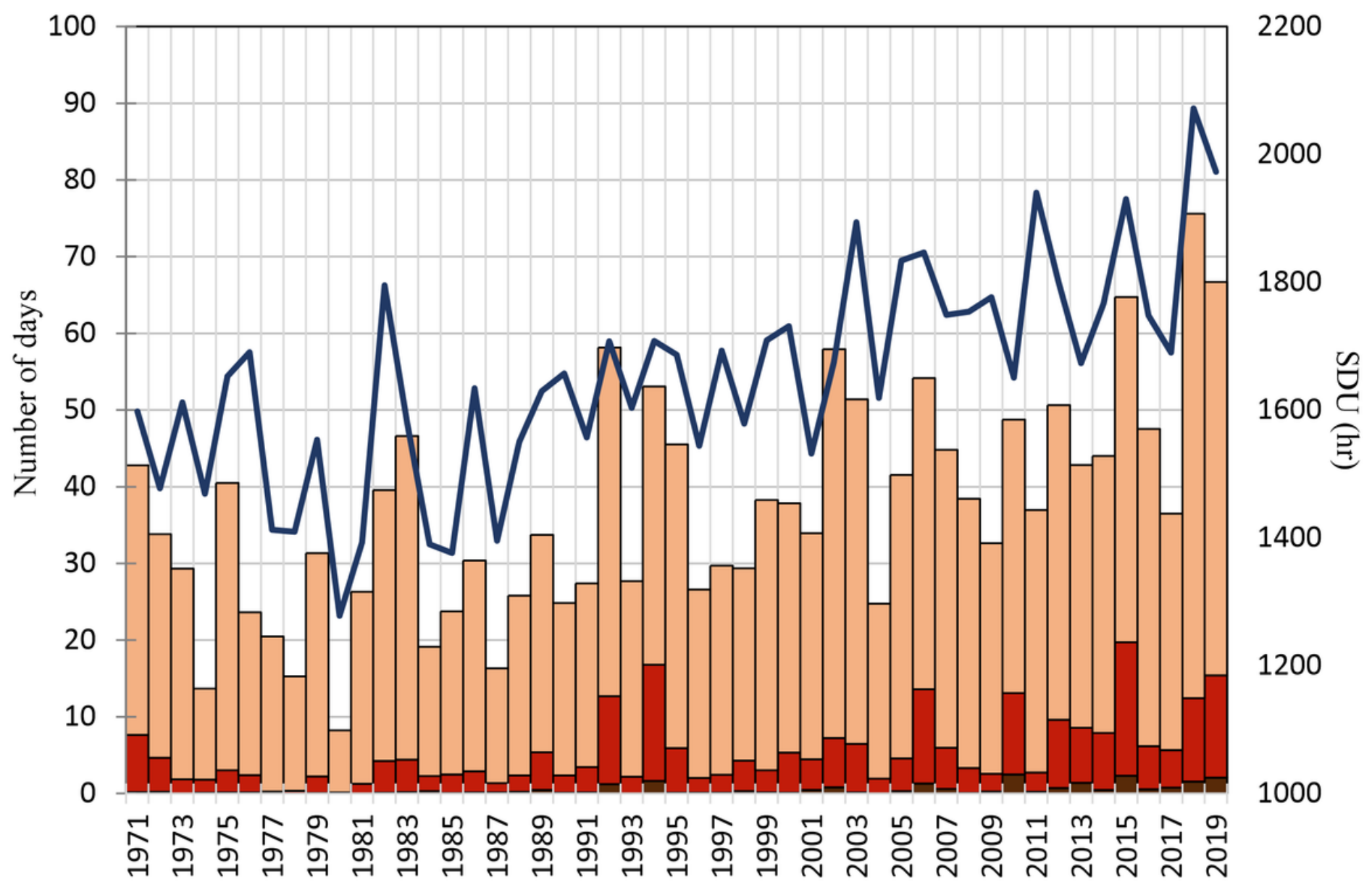

$\square$ Hot nights $\left(\operatorname{Tmin} \geq 20^{\circ} \mathrm{C}\right) \square$ Very hot days $\left(\operatorname{Tmax}>30^{\circ} \mathrm{C}\right) \square$ Hot days $\left(\operatorname{Tmax}>25^{\circ} \mathrm{C}\right) \longrightarrow$ SDU

Figure 5

The multi-annual course of area-average annual sunshine duration and the number of hot days $\left(\operatorname{Tmax}>25^{\circ} \mathrm{C}\right)$, very hot days $\left(\operatorname{Tmax}>30^{\circ} \mathrm{C}\right)$, and hot nights $\left(\operatorname{Tmin}>20^{\circ} \mathrm{C}\right)$ in Poland 


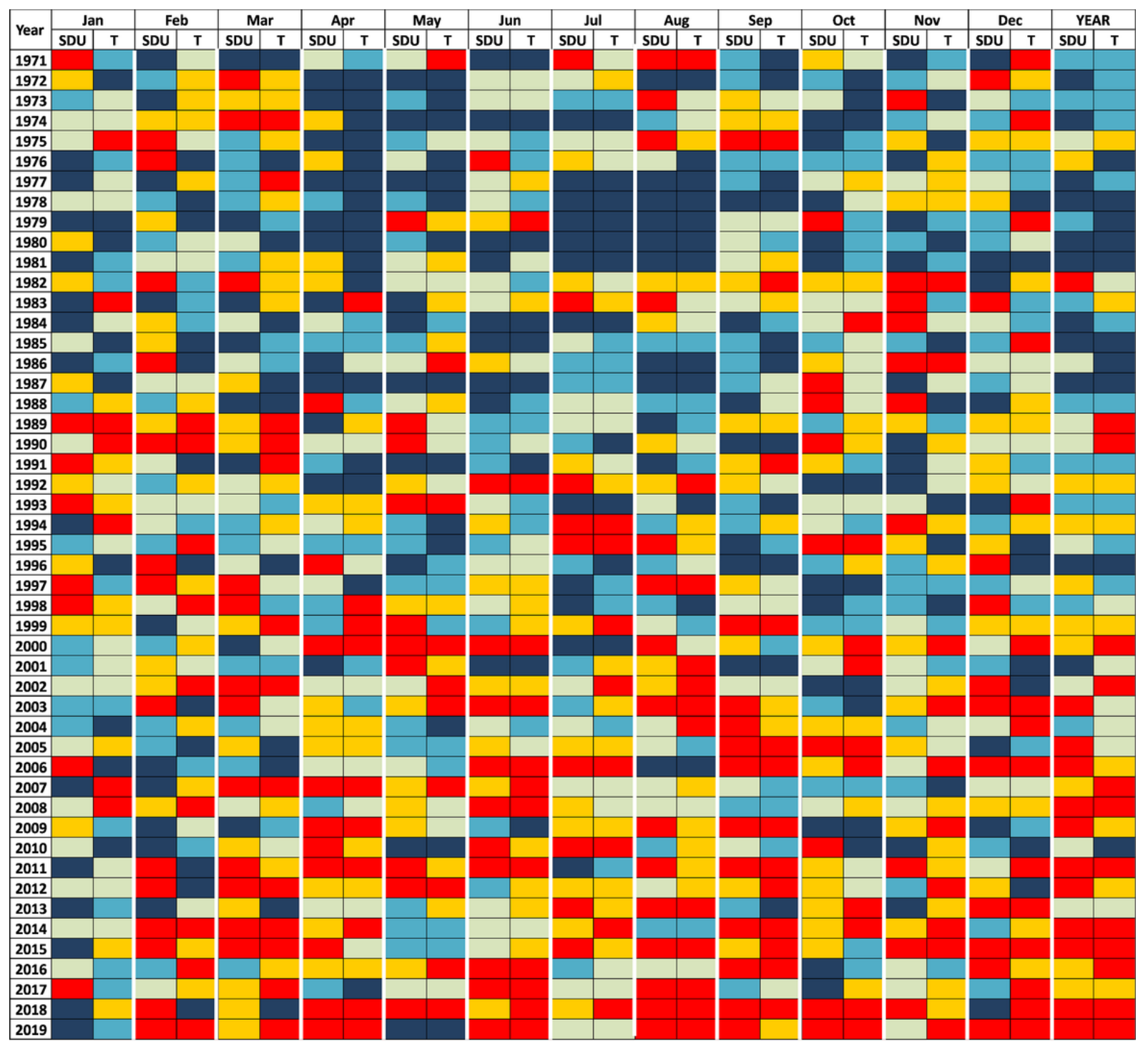

Class names and percentile ranges (\%) of SDU and T:

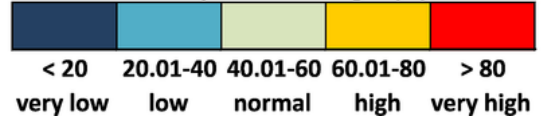

Figure 6

The five-element quantile classification of area-average monthly and annual sunshine duration as well as day-time air temperature in years 1971-2019 
a)

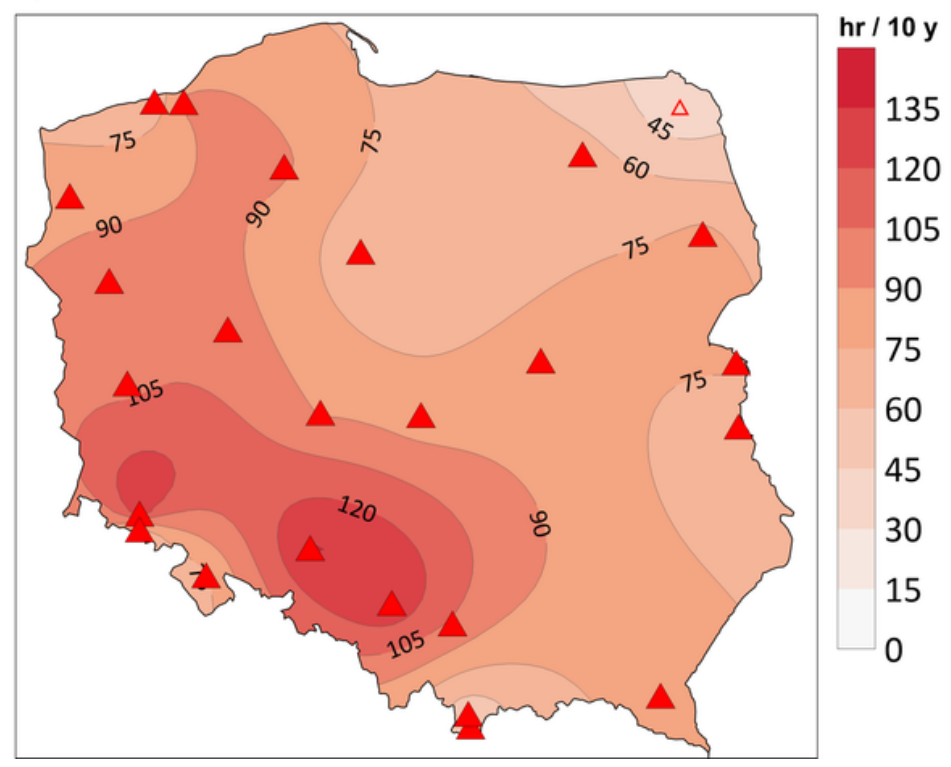

b)

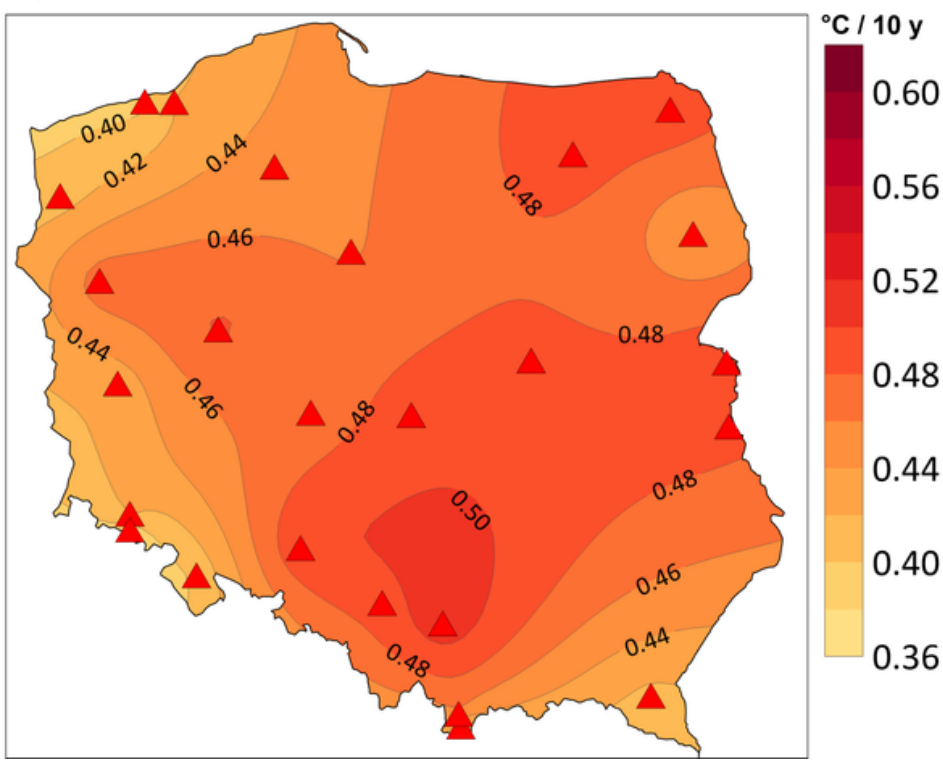

\section{Figure 7}

The magnitude (slope coefficient in hours and ${ }^{\circ} \mathrm{C} / 10$ years, respectively) and statistical significance of linear temporal trends in the annual (a) sunshine duration and (b) day-time air temperature at meteorological stations in Poland (1971-2019) 


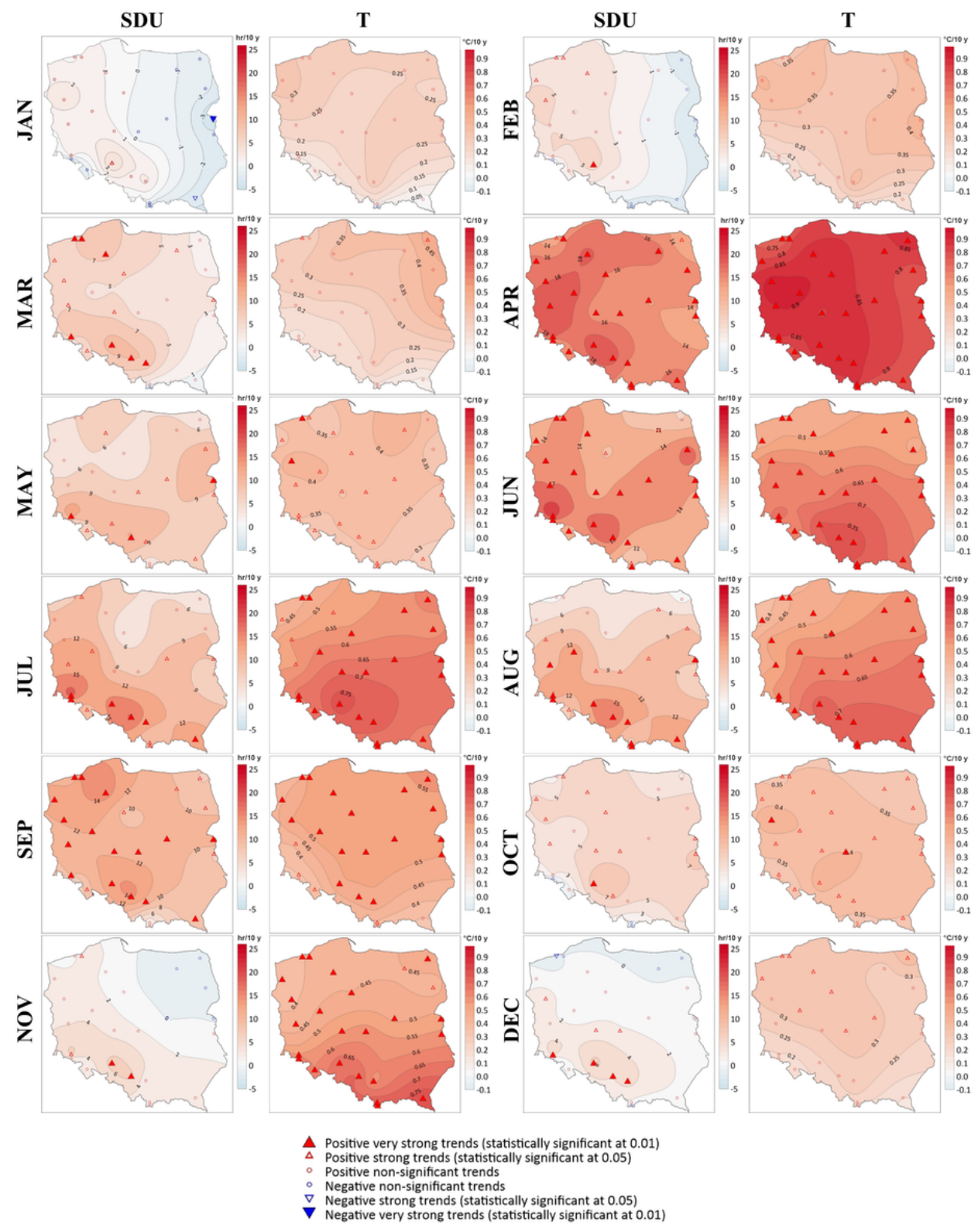

Figure 8

The magnitude (slope coefficient in hours and ${ }^{\circ} \mathrm{C} / 10$ years, respectively) and statistical significance of linear temporal trends in sunshine duration and day-time air temperature in selected months at meteorological stations in Poland (1971-2019) 


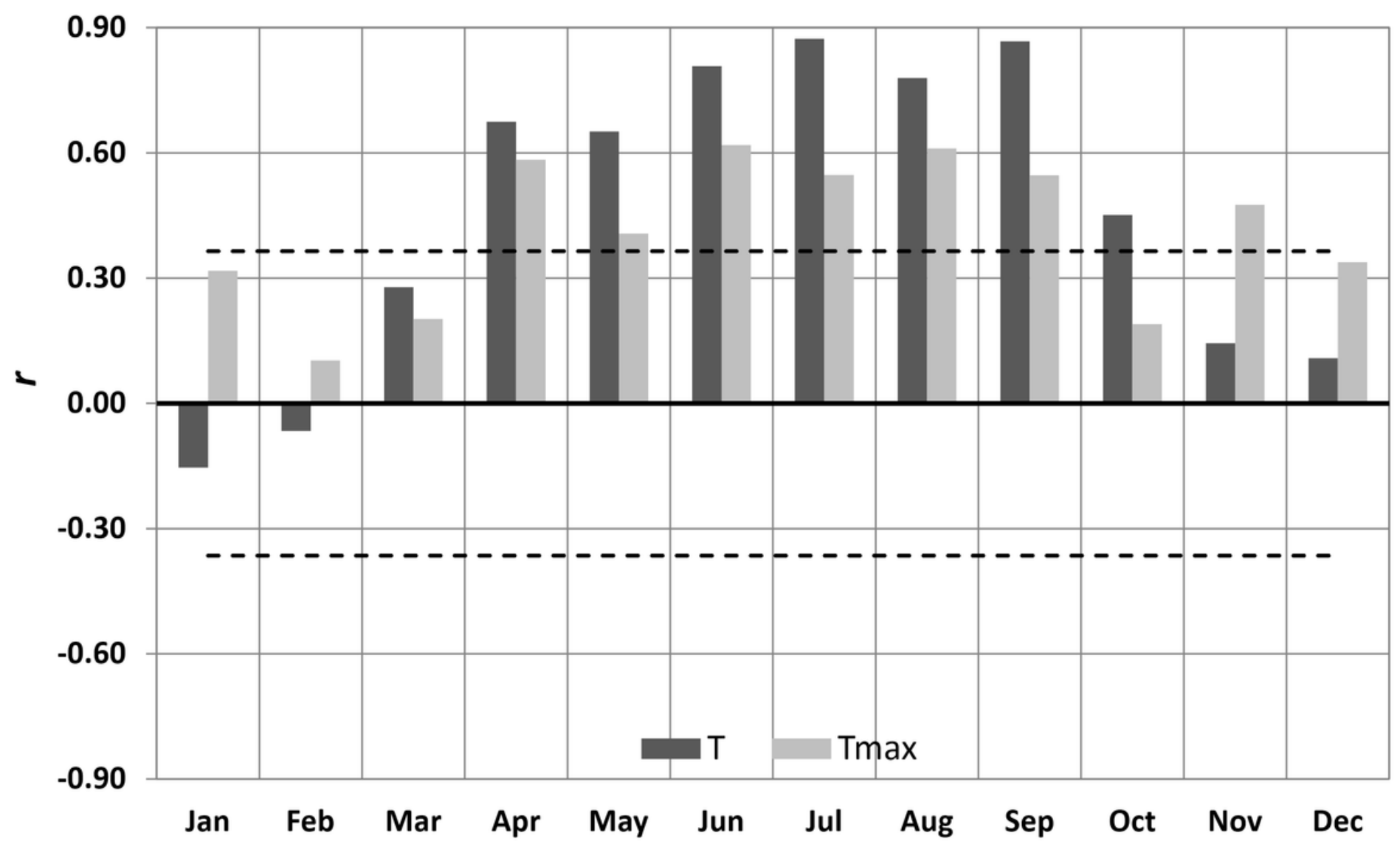

Figure 9

Correlation coefficients between the area-average monthly sunshine duration, day-time $(T)$ and daily maximum (Tmax) air temperature in Poland. Dashed lines indicate the level of statistical significance: $p<0.01$ 


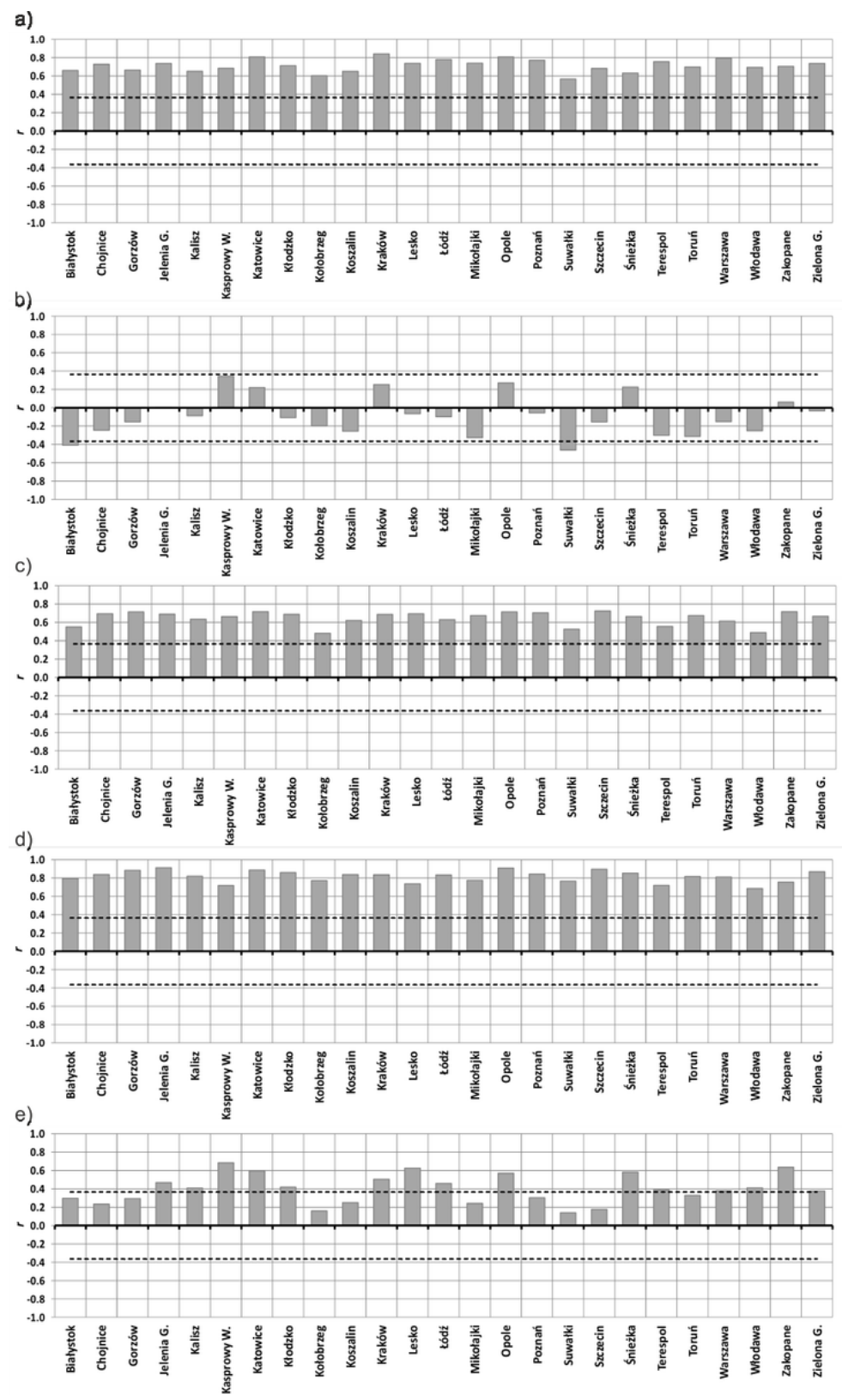

\section{Figure 10}

Correlation coefficients between the average totals of sunshine duration and the average day-time air temperature at individual stations. (a) annual average, (b) January, (c) April, (d) July and (e) October. Dashed lines indicate the level of statistical significance: $p<0.01$ 


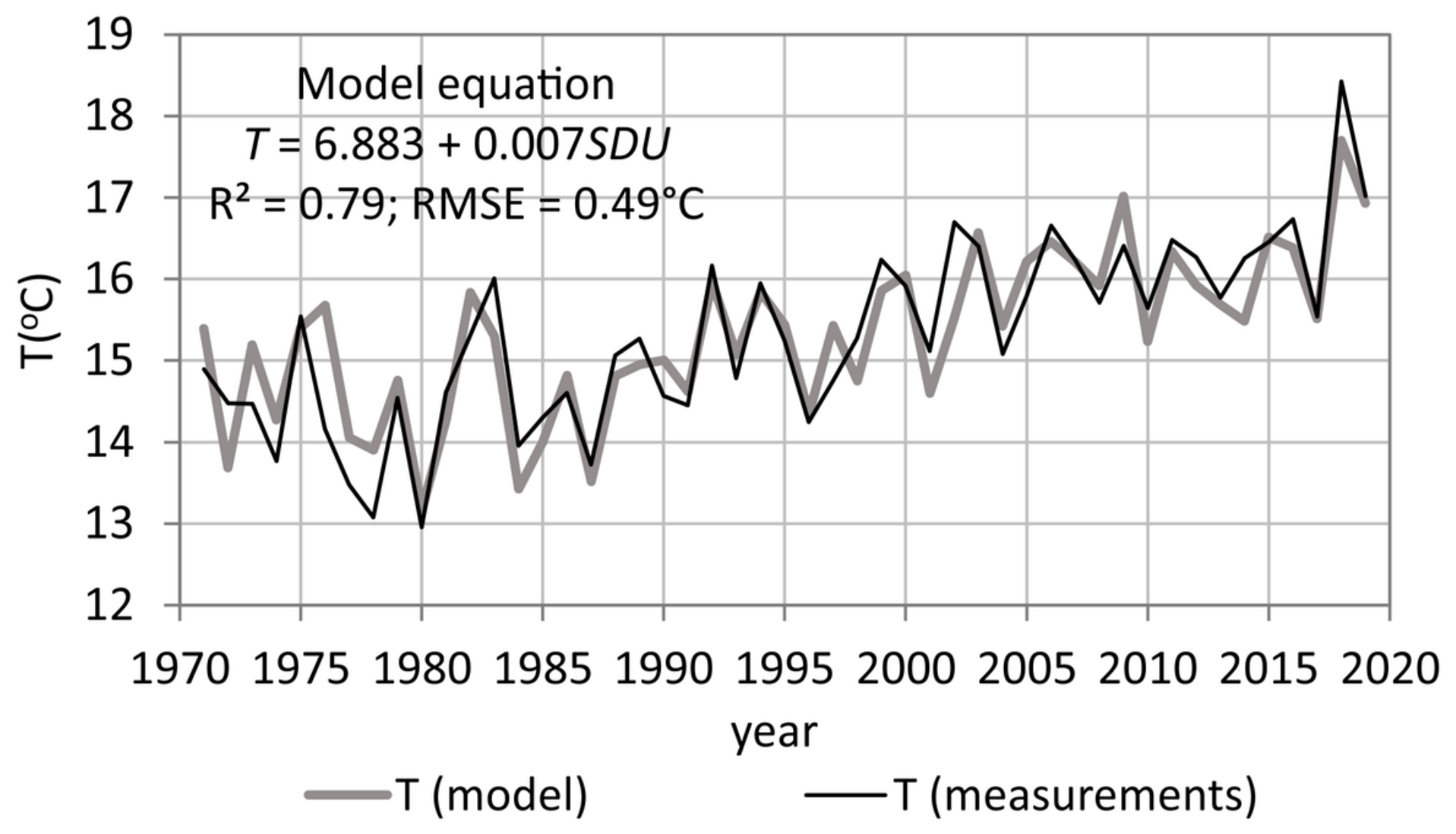

Figure 11

The multi-annual variability of area-average day-time air temperature from the period April-September in Poland in the years 19802019 calculated on the basis of measurements at meteorological stations (black line) and the linear regression model (1) (grey line) 